\title{
Sins of the Father: The Effect of a Parent Firm's Accounting Misconduct on Current and Former Subsidiaries
}

\author{
Alina Lerman \\ University of Connecticut \\ (860) 486-6240 \\ alina.lerman@uconn.edu \\ Steven Utke \\ University of Connecticut \\ (860) 486-2374 \\ sutke@uconn.edu \\ Jingyu $\mathrm{Xu}$ \\ University of Connecticut \\ (860) 486-5433 \\ jingyu.xu@uconn.edu
}

July 25,2020

Keywords: Restatement, Bankruptcy, Information Transfer, Management Reputation

JEL codes: G14, M41

Data Availability: Data used in this study are available from public sources identified in the paper.

We gratefully acknowledge the support of the University of Connecticut School of Business. Utke also appreciates the support of the School of Business Dean's Fund. This paper has benefitted from helpful comments from Ben Ayers, John Campbell, Jenny Luchs-Nuñez, Santhosh Ramalingegowda, Bridget Stomberg, Sunny Yang, and workshop participants at the University of Connecticut. 


\title{
Sins of the Father: The Effect of a Parent Firm's Accounting Misconduct on Current and Former Subsidiaries
}

\begin{abstract}
We exploit a unique setting to examine how managerial and economic connections affect the current and former subsidiaries ("subsidiaries") of a parent firm undergoing a restatement and bankruptcy. The demise of Enron and the varying nature of ties between Enron and its four publicly traded subsidiaries allow us to examine if capital market reactions for each of the subsidiaries surrounding Enron's failure vary with the nature of their connections to Enron. We observe no significant differences in contemporaneous market reaction regardless of the nature and strength of connections between Enron and the subsidiaries, providing two main insights. First, over the year following the Enron events, those subsidiaries with ownership or accounting ties but with weak economic ties performed in-line with the industry, consistent with the lack of a differential market reaction across these sets of firms. This result contrasts with recent studies finding evidence of manager fixed effects affecting accounting choices. Second, we find that Enron's most economically connected subsidiary (predictably) went bankrupt shortly after Enron, suggesting a market under-reaction at the time of the Enron events. Additional analysis provides some limited evidence that low institutional ownership or slow analyst forecast updating partly explains this under-reaction. Our study adds to the literature on restatements, management reputation effects, peer information transfer, and the market's ability to react to specific fundamental information.
\end{abstract}




\section{INTRODUCTION}

In this study, we exploit a unique setting to examine two important, previously unexplored research questions. Specifically, we study a setting where a parent firm with publicly traded current and former subsidiaries (henceforth, "subsidiaries") experiences a major restatement and bankruptcy. This setting allows us to examine a) the effect of a parent firm management's reputation on subsidiaries and b) the extent of information transfer between a parent and subsidiaries. To our knowledge, although auditor reputation has been studied with mixed results (e.g., Nelson, Price, and Rountree 2008; Weber, Willenborg, and Zhang 2008; Baugh, Boone, Khurana, and Raman 2019; Donelson, Ege, and Leiby 2019), management reputation has received little attention due to the limitation that managers typically only oversee one publicly traded firm at a time. ${ }^{1}$ While information transfer has been studied extensively (e.g., Foster 1981; Baginski 1987; Gleason, Jenkins, and Johnson 2008, among many others), these studies often use broad groupings to examine information transfer. Our unique setting allows us to examine whether a parent firm's a) managerial connections and b) economic connections to its subsidiaries affect the subsidiaries' market reactions and future operating performance around and after the parent's restatement and bankruptcy.

Prior studies find evidence of industry or geographic information transfer among peer firms around restatements and bankruptcies (e.g., Lang and Stulz 1992; Gleason et al. 2008; Jia and Zhao 2016). Since these studies focus on broad groups of peer firms, they potentially overlook specific cases where information transfer should occur (Hertzel, Li, Officer, and Rodgers (2008) and Boone and Ivanov (2012), discussed later, are notable exceptions but focus

\footnotetext{
${ }^{1}$ For the purposes of our study, management reputation captures the fact that managers have control over subsidiaries, and investors can potentially infer - from observing the parent firm - how managers will behave at subsidiaries. In our setting, parent managers can control a) a subsidiary's overall activities through the parent's ownership rights or b) a subsidiary's accounting through contractual agreements.
} 
only on financial distress). That is, while prior studies identify "on average" peer responses to restatements or bankruptcies, they are generally unable to specifically identify peer firms most likely to be impacted by the restatement or bankruptcy. ${ }^{2}$ Unlike prior literature, our unique setting allows us to test the market's ability to identify and react to specific connections between firms. Further, to our knowledge, no study has examined a bankruptcy or restatement where managers previously had or currently have substantial control over other publicly traded firms, including the accounting operations at those firms. ${ }^{3}$ As such, our study is the first to examine the effect of managerial connections on market response and operating performance of subsidiary firms' following a parent's restatement or bankruptcy.

Because prior research shows that parent firms can control their (private) subsidiaries' accounting choices (e.g., Dyreng, Hanlon, and Maydew 2012; Bonacchi, Cipollini, and Zarowin 2018), parent-subsidiary connections among public firms could be very important around a major restatement and bankruptcy. A parent misreporting its earnings could misreport the earnings of subsidiaries. However, given that investors have limited attention (e.g., Hirshleifer and Teoh 2003; DellaVigna and Pollet 2009; Hirshleifer, Lim, and Teoh 2009), this presents an important empirical question related to how investors perceive parent-subsidiary connections around a restatement and bankruptcy. Specifically, we ask whether a high profile restatement

\footnotetext{
${ }^{2}$ Several studies identify cross-sectional effects where, on average, the impact is likely to be stronger (e.g., for restatements: high accrual firms with the same auditor as the restating firm; for bankruptcies: firms in high leverage industries). In this study, we investigate whether investors identify the specific, highly connected subsidiaries most likely to be affected by a restatement or bankruptcy. Our ability to clearly identify connections reduces measurement error and omitted variables potentially existing in cross-sectional studies.

${ }^{3}$ Prior studies examine the labor market consequences to managers following accounting issues (e.g., Karpoff, Lee, and Martin 2008a; Groysberg, Lin, Serafeim, and Abrahams 2016). Our study differs substantially from this research because we focus on the effects of focal firm managers on related firms, concurrent with the accounting issues at the focal firm. While some studies examine management succession at a firm following its own accounting problems (e.g., Gangloff, Connelly, and Shook 2016), these studies do not track the manager to new firms, likely because managers face difficulty in obtaining equivalent employment after their turnover (e.g., Desai, Hogan, and Wilkins 2006). For a review related to boards and directors around restatements, see Street and Hermanson (2019).
} 
(bankruptcy) causes investors to a) question the accounting practices (economic prospects) broadly within an industry, as generally documented in prior literature, while ignoring direct parent-subsidiary connections, or b) focus on specific firms that are most directly connected to the restatement (bankruptcy). We exploit variation in both the parent-subsidiary connection and the event type in our study. We expect that the parent's restatement is more likely to affect subsidiaries with accounting/managerial connections to the parent, while the parent's bankruptcy is more likely to affect subsidiaries with economic ties to the parent. Because prior literature suggests that investors can underreact (Ramnath 2002) or overreact (Thomas and Zhang 2008) to peer firms' earnings disclosures, investors' responses to relevant peer information remains an open question.

In the spirit of Bowen, Castanias, and Daley (1983), Lamont and Thaler (2003), Weber et al. (2008), and le Bris, Goetzmann, and Pouget (2019), among many others, we focus on a unique setting with easily identifiable attributes - parent-subsidiary connections in our case - to investigate our research questions. Christensen (2019) discusses the importance of studies in these types of settings. We pick a significant restatement and bankruptcy event heavily studied in prior research: Enron (e.g., Chaney and Philipich 2002; McGill and Outslay 2002; Blouin, Grein, and Rountree 2007; Nelson et al. 2008; etc.). The Enron setting has two features important for our study. First, Enron was a massive and surprising accounting failure, providing the impetus for the Sarbanes-Oxley Act and the demise of Arthur Andersen, and was so notable that it continues to draw attention decades after the event. Second, Enron's unique corporate structure, different from that present in any other accounting failure that we are aware of, enables us to examine our research questions on the effects of parent-subsidiary connections.

Specifically, in order to conduct our analyses, we require several elements which only the 
Enron setting provides. First, as an accounting study, we require a major accounting event, such as a restatement, at a parent firm. Second, we require heterogeneous connections (e.g., not just an ownership interest) between a parent firm and several separate publicly traded subsidiaries. Enron is ideal for this because, prior to the early 2000s, Enron was a highly successful company that carved-out or spun-off several subsidiaries into separate publicly traded firms. By the time of Enron's collapse, its relationship with each of these subsidiaries varied in ways that generate predictable implications of Enron's restatement and bankruptcy on each subsidiary; we exploit these varying connections in this study. These relationships were easily identifiable from SEC filings and other reports at the time of Enron's bankruptcy. ${ }^{4}$

Specifically, at the time of its failure, Enron had four publicly traded subsidiaries, including entities within and outside of Enron's industry. In some cases, Enron retained significant control, including accounting responsibilities, and in some cases it had substantial contractual and economic ties with the entities. In brief, the four subsidiaries we examine are EOTT Energy (EOTT), Northern Border Partners (NBP), Kinder Morgan (KMP), and EOG Resources (EOG). Enron had a) significant economic ties to EOTT along with a controlling interest and control over EOTT's accounting, b) a controlling interest and control over NBP's accounting, c) no direct ties to KMP, and d) only a relatively small ownership interest in EOG. EOTT and NBP clearly stated their accounting and/or economic connections to Enron in their 10-K filings, and EOTT disclosed that Kenneth Lay was a director.

These relations allow us to examine our research questions. First, if restatements cause investors to question financial reporting quality (e.g., Gleason et al. 2008), then we expect the

\footnotetext{
${ }^{4} \mathrm{We}$ are not aware of a similar structure in any other significant accounting scandal (e.g., WorldCom, HealthSouth, Tyco). While Tyco may seem like a possible candidate given its post-scandal divestitures, before Tyco's 2002 scandal (i.e., per the 9/30/2001 10-K), Tyco had only carved-out one publicly traded subsidiary (TyCom, formerly Tyco Submarine Systems), which it fully reacquired in December of 2001.
} 
market to react more negatively to restatement news, compared to the overall industry, for entities most likely suffering from similar accounting issues to Enron (e.g., where Enron controls the subsidiary and the accounting: EOTT and NBP). Evidence of a more negative reaction for subsidiaries with direct or indirect management connections to Enron would support a management reputation effect. Second, if investors question the economic health of related firms around bankruptcy (e.g., Lang and Stulz 1992), then we expect entities most closely tied to Enron economically (EOTT) to experience worse market reaction than the industry as a whole following bankruptcy news. ${ }^{5}$ Because of the unique mix of attributes of each subsidiary, discussed in detail in Section 2.1, we are able to compare responses across subsidiaries to disentangle the management reputation effect from the effect of economic connections.

On the other hand, we may find no evidence of differential reactions to Enron's restatement or bankruptcy conditional on the subsidiaries' connections to Enron. First, if investors broadly lose confidence in accounting practices or future economic prospects in an industry following a restatement/bankruptcy, we will see no difference in market reaction for the subsidiaries closely tied to Enron versus the broader industry. Second, if investors are not fully aware of the parent-subsidiary connections, or underweight their importance, we will also see no differential market reaction for Enron-connected subsidiaries versus other industry firms. Lastly, to the extent that economic ties are more likely to have real effects than reputational ties, we will find differing responses for the subsidiaries based on the specific details of their connections to Enron. As such, understanding if and how the market reaction to a parent's restatement/

\footnotetext{
${ }^{5}$ Prior literature examines implications of bankruptcy in customer-supplier relationships (Hertzel et al. 2008) and in strategic alliances and joint ventures (Boone and Ivanov 2012). While Enron engaged in some sales transactions with its subsidiaries, these transactions generally did not rise to the level used to measure customer-supplier relationships in prior literature, and these relationships were not akin to joint ventures. As discussed later, Enron mainly provided accounting services (EOTT, NBP) and financial support (EOTT) to some subsidiaries. In addition, our setting involves both a restatement and a bankruptcy. Thus, our setting differs substantially from prior literature.
} 
bankruptcy varies with the relationship to its subsidiaries is an open empirical question.

To analyze the contemporaneous market reaction to the Enron events, we focus on three specific events around Enron's failure. Between October 16 and October 22, 2001, Enron initially acknowledged the possibility of accounting errors and related SEC inquiries (treated as one event). On November 8, 2001, Enron formally announced a restatement affecting its financial statements from 1997 to 2000. On December 2, 2001, Enron filed for bankruptcy. We examine the industry and subsidiary reactions to the Enron announcements around these days.

While we find, in general, a negative industry-wide reaction to the Enron events, we find no difference between the industry-wide reaction and the reaction of the subsidiaries, including those where Enron controlled the accounting or had close economic ties. Although there is a lack of incremental market reaction at the announcement of the Enron events, examining the market reaction and accounting performance in the period following the Enron events provides insight into the appropriateness of the announcement reactions, specifically for subsidiaries likely to suffer direct consequences from Enron's failure (EOTT and NBP). That is, this analysis allows us to determine whether or not the market under-reacted to the Enron events.

We examine future performance over various periods following the Enron events. For the subsidiary with only accounting ties to Enron (NBP), we find no evidence that it performed worse than its peers. That is, somewhat surprisingly, a firm with direct accounting connections to Enron suffered no adverse consequences (beyond any industry-level consequences) to Enron's demise. While, in hindsight, this firm suffered no negative effects from Enron's accounting, the lack of market reaction to each Enron event is consistent with limited attention in that investors may not have been fully aware of Enron's role in the accounting at this subsidiary.

In contrast, we find that the former subsidiary most likely to suffer economic 
consequences from the Enron restatement and bankruptcy (EOTT) earned significantly lower market returns than the industry in the six months after the Enron events. Moreover, this subsidiary went bankrupt shortly after Enron. This result suggests that the market failed to immediately incorporate the information about the economic connections between Enron and EOTT into market prices upon Enron's bankruptcy announcement. For example, EOTT's SEC filings indicated it received important financial support from Enron, which was clearly jeopardized upon Enron's bankruptcy. In addition, the evidence is consistent with limited attention preventing investors from identifying specific connections relevant to the accounting failure and instead focusing on the broad, industry-wide implications of Enron's failure. ${ }^{6}$

In additional analysis, we examine a possible explanation for the lack of market reaction in subsidiaries with control and/or economic links. Consistent with prior evidence that sophisticated information users have advantages in acquiring and processing information (e.g., Bushee 1998; Ayers and Freeman 2003), we hypothesize that information transfer is greater among firms with higher levels of sophisticated information users: institutional investors and financial analysts. Consistent with this prediction, we find a negative reaction to Enron events only among industry peers with above-median institutional ownership. The three Enron subsidiaries in its industry (NBP, EOTT, KMP) all have below-median institutional ownership suggesting that the absence of informed investors may be behind the unexpected lack of results around the Enron events. In contrast, we do not find a significant difference in market reaction between peer firms with above median versus below median analyst coverage. The three Enron

\footnotetext{
${ }^{6}$ Nelson et al. (2008) find that industry-specific economic conditions, rather than Enron/Arthur Andersen specific connections as argued by Chaney and Philipich (2002), drove negative reactions previously identified around Enron events. That is, Chaney and Philipich's (2002) finding that Arthur Andersen clients experience negative market reactions to the Enron events (i.e., a "reputation" effect) does not hold after controlling for industry effects. We avoid this concern by focusing within Enron's industry. Overall, we argue that the entities most closely tied to Enron should be most vulnerable to negative economic conditions, more so than the industry, and information identifying these connections was publicly available well before the Enron events.
} 
subsidiaries in its industry (NBP, EOTT, KMP) all have above median-analyst coverage. As such, we also examine analysts' forecast updating behavior. That is, high coverage may not matter if analysts are inactive. We find that analysts update forecasts more slowly for EOTT than for the other subsidiaries, suggesting that a particularly weak information environment could be responsible for EOTT's lack of a market reaction upon Enron's bankruptcy.

This paper makes several contributions to the literature. First, to our knowledge, we are the first to examine the effect of managerial reputation on subsidiaries around a restatement and bankruptcy. We find that the market reaction is not more negative for subsidiaries with managerial connections to the restating firm. This is consistent with either the market viewing the parent's accounting issues as immaterial to subsidiaries, or with investors overlooking connections due to limited attention, and is inconsistent with manager fixed effects affecting accounting choices (see also Fee, Hadlock, and Pierce 2013). Second, we contribute to our understanding of the contagion and peer (or information transfer) effects of restatements and bankruptcies. We document that the market fails to identify subsidiaries that are likely to suffer from the parent's restatement and/or bankruptcy, which is consistent with limited investor attention. A weak information environment may play a role in the under-reaction to Enron's bankruptcy announcement. Because small firms, likely facing the highest risks, especially regarding bankruptcy, often operate in weak information environments (e.g., Atiase 1985), our results should be of interest to academics, regulators, and investors focusing on small firms.

Our results complement recent work by Ginglinger, Hebert, and Renneboog (2018) finding that investors are not fully aware of ownership connections between parent and subsidiary firms around earnings announcements. We go beyond their study by examining a much more substantial event with more varied relations between the parent and subsidiaries. Our 
findings contrast with Fich and Shivdasani (2007) who find that firms with director (rather than manager) connections to fraud firms suffer valuation consequences. This difference could arise because we examine firms in related industries, whereas board connections need not be withinindustry. This would suggest that our results are driven by limited attention of investors, reacting to a negative industry shock, who fail to identify firm-specific ties within an industry.

\section{BACKGROUND, PRIOR LITERATURE, AND HYPOTHESES}

\subsection{Background and Setting}

Enron was founded in 1985 following the merger of two natural gas firms, Houston Natural Gas and InterNorth. Energy industry deregulation in the 1980s and 1990s led to Enron's rapid expansion, including its entry into new geographies and industries. This growth and change enabled Enron to carve-out or spin-off several subsidiaries. Panel A of Table 1 provides a brief summary of Enron's subsidiaries and the nature of connections between them and Enron. ${ }^{7}$ The first publicly traded carve-out from Enron was Enron Liquids Pipeline (effective 7/30/1992). While Enron was initially heavily involved in the operations and management of this entity, Enron had fully divested itself of the entity by the middle of 1997, when Kinder Morgan acquired Enron's interest in the entity. The entity became Kinder Morgan Energy Partners (KMP) at this time. Because, at the time of Enron's failure, Enron no longer controlled this entity and the entity was no longer named after Enron, this entity is unlikely to suffer significant direct or indirect consequences from Enron's failure. However, Kinder Morgan co-founder Richard Kinder had strong ties to Enron, previously serving as Enron's president and working closely

\footnotetext{
${ }^{7}$ We focus on a narrow setting that enables us to clearly identify effects of interest. These types of studies provide new insight unavailable in broad studies (Christensen 2019), with countless economics (e.g., Lamont and Thaler 2003; Hoffman, Kahn, and Li 2018; Eliason, Heebsh, McDevitt, and Roberts 2020), finance (e.g., le Bris et al. 2019), and accounting (e.g., Weber et al. 2008; Deller and Sandino 2019) studies taking a similar approach.
} 
with Enron's CEO, Kenneth Lay (Creswell 2003). As such, certain connections to Enron may have remained relevant to investors or to KMP at the time of Enron's failure.

The second publicly traded carve-out from Enron was Northern Border Partners (NBP) (effective 9/23/1993; subsequently known as ONEOK Partners). While Enron only owned a relatively small portion of NBP (approximately 12\%), Enron had a controlling interest in this entity at the time of Enron's restatement. As a matter of law, partnerships are controlled by their general partner, with the other limited partners having limited control rights. Enron controlled $82.5 \%$ of the general partner of NBP, effectively granting it control of NBP. Further, Enron controlled NBP's operations, and most importantly, controlled NBP's accounting. This type of arrangement is common in publicly traded partnerships. These partnerships typically have few or no employees, with the actual accounting and operations performed by employees of the parent company (here, Enron). While some employees may specifically focus on only the partnership, many employees perform their role identically for both the parent and the partnership (e.g., payroll, inventory, insurance, pensions, etc.), often in what is referred to as a "shared services center." ${ }^{\prime 8}$ Further, five of NBP's top seven (71\%) executives and members of NBP's management committee (which is similar to a Board of Directors) had direct or indirect connections with Enron. While restatements cause investors to question the accounting practices of an industry (e.g., Gleason et al. 2008), the fact that Enron controls NBP's accounting and has deep connections with NBP's management team suggest that NBP is likely to have similar accounting practices to Enron, which should draw investor scrutiny following Enron's restatement.

\footnotetext{
${ }^{8}$ NBP's 2000 10-K states: “As is commonly the case with publicly-traded partnerships, we do not directly employ any of the persons responsible for managing or operating the Partnership or for providing it with services relating to its day-to-day business affairs. We have entered into an ... Agreement with ... Enron, pursuant to which [Enron] provides tax, accounting, legal, cash management, investor relations, operating and other services for the Partnership." EOTT, discussed next, has similar language in its 10-K.
} 
The third publicly traded carve-out from Enron was EOTT Energy (EOTT) (effective 3/18/1994; subsequently known as Link Energy). ${ }^{9}$ Similar to NBP, Enron controlled EOTT (100\% general partner ownership in this case), EOTT's operations, and EOTT's accounting. Kenneth Lay, Enron's CEO who was convicted of securities fraud his role in Enron's failure, served on EOTT's board of directors. Among EOTT's top eleven executives and directors, eight (73\%) had direct or indirect connections with Enron. Further, Enron had large ownership in EOTT leading up to Enron's restatement (1997-2001, ranging from 49\% to 37\%) and was more economically tied to EOTT than any other former subsidiary. Specifically, while Enron only accounted for approximately $3.5 \%$ to $6.3 \%$ of NBP's revenues, as of the quarter before the Enron bankruptcy, EOTT had an available $\$ 1$ billion credit facility with Enron (at 12/31/2000, about $\$ 562$ million was used). ${ }^{10}$ Further, EOTT financed many recent acquisitions by borrowing from Enron, purchased former Enron assets for $\$ 117$ million (of which approximately $\$ 30$ million was for 10-year contracts with Enron that became worthless upon Enron's bankruptcy), and Enron had guaranteed EOTT's cash distribution to shareholders. Enron's guarantee of EOTT's distribution is particularly notable because, in EOTT's industry, the certainty and viability of cash distributions are extremely important and vital to attracting investors (Shaw and Wier 1993; Morningstar 2019). As such, on top of the direct control and accounting connections between EOTT and Enron, which were similar to that of NBP, EOTT's economic survival was closely tied to that of Enron. Therefore, EOTT is most likely to face scrutiny about accounting practices as well as operational concerns around Enron's failure.

\footnotetext{
${ }^{9}$ EOTT stands for "Enron Oil Trading and Transportation," however the firm's official name was EOTT Energy.

10 The threshold for identifying supplier-customer relations in prior literature is $10 \%$ (Hertzel et al. 2008), although firms do not always comply with this disclosure regulation (Legoria, Reichelt, and Soileau 2018). We are not studying a customer-supplier relation as studied in prior literature, but rather a parent and controlled subsidiary relationship. In EOTT's case, this relation involves significant financing and asset/liability related ties.
} 
Finally, Enron spun out EOG Resources (EOG) on 8/16/1999. ${ }^{11}$ By the time of Enron's failure, Enron owned only $9.2 \%$ of EOG and was not involved in its operations. Similar to KMP, this entity is unlikely to suffer direct consequences from Enron's restatement. ${ }^{12}$ Further, after the spin out of EOG, Enron effectively exited the oil and gas exploration industry. However, EOG's prior connections to Enron may cause it to have a more negative market reaction to the Enron events than the rest of EOG's industry, which Enron is not a member of.

\subsection{Prior Literature and Hypotheses}

\subsubsection{Parent-Subsidiary Relations}

A recent but rapidly growing literature examines the relationship between parent firms and subsidiary firms. In general, these studies find that parent firms exert extensive influence over (often private) subsidiary firms. These studies identify situations where parent firms (including private equity and similar funds) control the operating, financing, and accounting decisions of subsidiaries (e.g., Kaplan 1989; Acharya, Gottschalg, Hahn, and Kehoe 2013; Cohn, Mills, and Towery. 2014; Cornelli and Karakaş 2015; Hellmann and Puri 2002; Badertscher, Katz, and Rego 2013; Beaver, Cascino, Correia, and McNichols 2019; Larrain, Sertsios, and Urzúa 2019; see Mason and Utke 2019 for a review).

Perhaps most relevant to our setting, a string of recent studies show that parent firms exercise substantial control over earnings management at subsidiaries (e.g., Morsfield and Tan 2006; Katz 2009; Dyreng et al. 2012; Goktan and Muslu 2018; Bonacchi et al. 2018, 2019).

Given this evidence, we propose that accounting and managerial connections between Enron and certain subsidiaries could be important to the market's evaluation, and the future performance, of

\footnotetext{
${ }^{11}$ While EOG stands for "Enron Oil and Gas," at the time of the spin-off, the name was officially changed to EOG.

${ }^{12}$ In EOG's 2001 10-K, filed after Enron's failure, EOG explicitly states that all of its board members that were officers or directors of Enron relinquished their board seats on the spin-off date, indicating the existence of reputational concerns for EOG.
} 
those subsidiaries. However, most prior studies examine private subsidiaries; parent-subsidiary connections could be less relevant for a publicly traded subsidiary (e.g., because public firms are subject to SEC regulation, etc.). Our setting also consists of a major restatement involving fraud, whereas prior studies examine "routine" earnings management. It could be more difficult for managers to commit fraud than earnings management across multiple entities. Finally, while recent work by Ginglinger et al. (2018) find some evidence suggesting that subsidiary investors are inattentive to parent firm ownership links at earnings announcement, investors could be more aware of these connections given the magnitude of the restatement and bankruptcy that we study.

\subsubsection{Information Transfer}

A substantial body of literature examines information transfer among firms. Studies examine earnings announcements, management forecasts, analyst forecasts, bankruptcies, and stock prices, among others (e.g., Foster 1981; Baginski 1987; Hertzel and Officer 2012; Foucault and Fresard 2014; Hope and Zhao 2016). ${ }^{13}$ Recent accounting research more specifically focuses on information transfer (i.e., contagion) effects of restatements, examining the effect of a restatement on peer firms' valuation and investments, among others (e.g., Kravet and Shevlin 2010; Beatty, Liao, and Yu 2013; Jia and Zhao 2016; Li 2016). ${ }^{14}$

Because this literature is voluminous, we focus our discussion on the most closely related studies. Regarding restatements, Gleason et al. (2008) find that non-restating industry peer firms experience negative market reactions to a peer's restatement and that the effect is stronger for

\footnotetext{
13 The information transfer literature is massive, and we cannot discuss it all here. Additional studies include Firth (1976, 1996), Fu (2016), Silvers (2016), Brochet, Kolev, and Lerman (2018), Brown, Tian, and Tucker (2018), Chen, Miao, and Valentine (2018); Lee, Sun, Wang, and Zhang (2019). Recent finance literature focuses on "real effects" of information transfer, such as investment effects and dividends (e.g., Dessaint, Foucault, Frésard, and Matray 2018; Grennan 2018). Additional "real effects" studies include Kaustia and Rantala (2015), Benmelech, Bergman, Milanez, and Mukharlyamov (2018), Gantchev, Gredil, and Jotikasthira (2018), Addoum, Kumar, Le, and Niessen-Ruenzi (2019); Bernile and Lyandres (2019); Décaire, Gilje, and Taillard (2019).

${ }^{14}$ Again, we cannot discuss all studies in this vast literature on restatement-related information transfer, including Kedia, Koh, and Rajgopal (2015), Cao, Fan, Narayanamoorthy, and Rowe (2018), Guo, Kubick, and Masli (2018).
} 
firms with high accruals and for firms that share an auditor with the restating firm. Regarding bankruptcy, Lang and Stulz (1992) find that a focal firm's bankruptcy generally has negative effects on the firm's industry competitors and these negative effects are stronger for peer firms with higher leverage. Both of these studies suggest that we should observe negative industrywide market reactions to the Enron events. Auditor connections, which we discuss later, may also affect market reactions.

However, it remains an open empirical question as to the extent that investors can identify and react to the specific connections between Enron and its subsidiaries. Prior research finds evidence of both over- and under-reactions by peer firms at earnings announcement (Ramnath 2002; Thomas and Zhang 2008). However, the effect of specific connections between firms is even less clear. Ginglinger et al. (2018) examine information transfer effects of earnings announcements for firms with firm-to-firm ownership connections. They generally find mixed results and conclude that at least some parent firm investors and some subsidiary firm investors are not aware of the ownership connections between firms and of the implications of these connections for the other firms' earnings. In contrast, Bae, Cheon, and Kang (2008) find that in Korean business groups (chaebols), earnings announcements of affiliates have positive spillover effects on other affiliates. Joe and Oh (2018) find similar effects around credit rating announcements for chaebols. However, chaebols may have particularly well known and wellestablished links (Joe and Oh 2018), making it particularly easy for investors to pay attention to relevant peer information. In fact, Ko (2018) shows that peer effects in the Korean setting vary based on the connected firms' use of the family name where family names (or otherwise similar names) appear to make it easier for investors to make connections between firms, with less reaction to firms not sharing a name. The Enron setting is unique because the events are much 
more substantial than a typical earnings announcement; however, the salience of the connections to investors is likely lower than that in the Korean setting. We note that at the time of Enron's failure, none of its subsidiaries had "Enron" in their official names.

Regarding reputation effects, some studies examine reputational effects of executives or firms. For example, Nam, Ronen, and Ronen (2018) find that following an executive's departure, negative events at the executive's former firm (e.g., restructurings) have negative consequences for the executive's current firm. McDonnell and Pontikes (2018) show that firms connected to BP suffer negative consequences following the Deepwater Horizons accident. Auditor reputation is also a commonly studied reputational area, perhaps because a single auditor serves many publicly traded clients. Chaney and Philipich (2002) document negative reputational consequences to auditors, measured by negative market reactions for Andersen clients, following Enron's failure. However, Nelson et al. (2008) show that this reaction was driven by industry effects, not Andersen effects. Weber et al. (2008) and Dee, Lulseged, and Zhang (2011) find negative market reactions to clients of auditors surrounding an accounting scandal and regulatory sanctions, respectively. Gul, Lim, Wang, and Xu (2019) find audit partner-level contagion associated with financial reporting fraud. ${ }^{15}$

Based on prior research, we expect within-industry information transfer to occur around all three Enron events: initial announcement of accounting issues, restatement announcement, and bankruptcy announcement. Therefore, we propose the following baseline hypothesis:

H1: Enron's industry will have negative abnormal returns around the three Enron event dates.

\footnotetext{
${ }^{15}$ Several other studies similarly find mixed evidence of reputation effects for auditors (e.g., Baugh et al. 2019; Donelson et al. 2019). For the 12/31/2000 year end, KMP was audited by PwC, Houston, Texas; NBP was audited by Andersen, Omaha, Nebraska; EOTT and EOG were both audited by Andersen, Houston, Texas.
} 
We acknowledge that this is a replication of prior work, but we use it to lead into our main hypotheses. For our main hypotheses, we make predictions specifically related to Enron's relationship with each of its former subsidiaries. We focus on each subsidiary separately. First, we examine KMP. KMP has relatively weak ties to Enron at the time of Enron's failure, with no ownership by Enron. As such, we make the following null prediction:

H2a: A subsidiary with limited ties to the failing firm will experience a market reaction similar to the rest of the industry around the parent's failure.

This result will not hold if the prior ties to Enron (e.g., Enron's past ownership or the connections between Richard Kinder and Enron; Creswell (2003)) draw investor's attention. Next, we turn our attention to a more connected subsidiary, NBP. At the time of Enron's failure, Enron controls NBP, is entirely responsible for NBP's accounting, and has some limited economic ties to NBP. Although the prior literature on reputation effects in different settings is mixed, because of Enron's significance as an accounting failure, we predict that the market reaction will be more negative for NBP than the rest of Enron's industry.

H2b: A subsidiary controlled by the failing firm, where the failing firm performs accounting tasks, will experience a more negative reaction to the parent's failure than the rest of the industry.

However, this relation is not certain to hold. Limited attention could prevent investors from understanding and reacting to the connections between Enron and NBP, especially because NBP is not named after Enron (e.g., Ko 2018). We would also observe no incremental negative market reaction if the market can determine that the accounting issues specific to Enron are unlikely to extend to other entities where Enron performs the accounting.

Our next hypothesis focuses on EOTT. Like NBP, Enron controlled EOTT and performed the accounting at the time of Enron's failure. Unlike NBP, EOTT was heavily 
dependent on capital from Enron, obtaining a \$1 billion credit facility and relying on Enron to finance recent acquisitions and, more importantly, distributions to shareholders. Absent this support, EOTT's economic viability is likely to be highly uncertain. Therefore, we predict that the market reaction will be more negative for EOTT than the rest of Enron's industry.

H2c: A subsidiary with strong economic ties to the failing firm will experience a more negative reaction to the parent's failure than the industry.

Again, however, we may not observe this relation if limited attention prevents investors from fully understanding these parent-subsidiary links (e.g., Ginglinger et al. 2018). We note that because we separately examine NBP (control only) and EOTT (control and economic ties), we can disentangle whether any market reaction is associated with control/accounting oversight or economic connections. Finally, we examine EOG. EOG had limited ties to Enron at the time of Enron's failure, with Enron only owning a small portion of the firm. EOG also operated in an industry that Enron no longer operated in. As such, EOG's limited connection to Enron could cause it to have a lower market reaction than the rest of the industry, which could be otherwise shielded from the Enron events. On the other hand, the weak connection could limit any market reaction. As such, we propose the following null hypothesis.

H2d: A subsidiary outside of the failing firm's industry will experience a market reaction similar to the rest of the industry around the parent's failure.

After examining the market reactions to the Enron events, we examine the subsidiaries' ex-post performance (market returns and ROA), focusing on the subsidiaries most directly connected to Enron: NBP and EOTT. If Enron's accounting issues spill over to NBP, we expect to observe a negative post-failure performance for NBP. If EOTT suffered from losing economic support from Enron, we expect it to perform poorly following Enron's failure. 
H3a: A subsidiary controlled by the failing firm, where the failing firm performs accounting tasks, will have lower future performance than its industry peers.

H3b: A subsidiary closely tied to the failing firm economically will have lower future performance than its industry peers.

If these connections are relatively weak, however, we will observe no results. This analysis also provides insight into evaluating the market response at the Enron events. That is, (lack of) negative market reaction to the Enron events should be accompanied by (lack of) negative performance after the Enron events.

In addition to these hypothesized relations, we also perform cross-sectional tests related to the information environment at the subsidiaries. We measure the information environment using institutional ownership and analyst forecasts. The information environment could have varying impacts on our results. Specifically, a stronger information environment should enhance the ability of investors to evaluate the effects of the Enron events on each of the subsidiaries. However, given that prior literature finds both evidence of over- and under-reaction to peer events, we make no predictions on the impact of the information environment in our setting. For example, given the magnitude of the Enron failure, and the substantial uncertainty caused for the energy industry, regulation, and the market overall, a better information environment could enhance over-reaction by highlighting connections between Enron and its subsidiaries.

\section{SAMPLE SELECTION AND DATA}

We obtain our data from the intersection of Compustat and CRSP from 2000 to 2002 and keep firm-years within industries relevant to our tests. According to Compustat, Enron is classified in SIC 5172 (Petroleum and Petroleum Products Wholesalers, Except Bulk Stations and Terminals) in the year before its restatement. Enron's 2000 10-K states that its principal 
businesses consist of: transportation of natural gas through pipelines; electric generation, transmission, and distribution; marketing of natural gas and electricity; development, construction, and operation of power plants and pipelines; and delivery of energy commodities to customers. As such, we also include several additional SICs to properly capture Enron's industry: 5171 (Petroleum Bulk Stations and Terminals; largely equivalent to Enron's Compustat SIC of 5172, and also EOTT's main business), 4610, 4612, 4613, 4619 (broadly, SIC 46XX covers Pipelines, excluding Natural Gas, and is also KMP's main business as well as a business of EOTT), and 4922/4923 (broadly, this is Natural Gas Pipelines, and is NBP's main business as well as a business of EOTT and KMP). We believe these industry classifications appropriately reflect Enron's main businesses. We note that EOG's SIC is 1311, with 1321 and 1381 closely related (broadly, Oil and Gas extraction). Enron no longer operated in this industry at the time of its restatement. Table 1, Panel A presents details of each of Enron's subsidiaries.

After requiring these industries, we require daily returns from CRSP to calculate cumulative abnormal returns within the 11-day trading windows $(-5,5)$ around each of the Enron events, which are presented in Table 1, Panel B. After dropping observations missing required data, our final sample consists of 176, 175, 174, and 176 observations (excluding Enron) for the three events and the 6 months after the last event date, respectively. In addition, we separately identify firms that are in the same industry as Enron (37, 37, 37, and 40) and those are in the same industry as EOG $(139,138,137$, and 136) around each of the events because we perform most of our comparisons between each subsidiary versus the other firms in its industry. Table 1, Panel C presents our sample selection.

\section{INSERT TABLE 1}

In Figure 1, we compare the cumulative return trends of the three subsidiaries in Enron's 
industry (KMP, NBP, and EOTT) with that of the peer firms from January 2001 to August 2002

(we do not include EOG since it is outside of Enron's industry). Panel A presents the period from January to June 2001. In the period leading up to the Enron events, the subsidiary and industry returns move in line with one another, although the subsidiaries have slightly higher performance. Panel B covers the period from July to December 2001, which includes the Enron events. Overall, the subsidiaries and peer firms have similar cumulative return trends over this period, although the subsidiaries initially outperform the industry. Both groups also move in line around the first two Enron events (October 22 and November 8), with both registering declines. A more notable decline occurs around the third Enron event (December 2), especially for the subsidiaries. ${ }^{16}$ However, the firms recover relatively quickly following the drop. Overall, Panel B shows that the subsidiaries experienced more negative returns around Enron's events, but as we see in Section 4, high standard errors lead to no significant differences between the returns. Panel C presents cumulative returns for the three subsidiaries and the industry from January to August 2002. ${ }^{17}$ The trends show that the market reacts more negatively to the subsidiaries in the period after the collapse of Enron. In Section 4, we show this is driven by EOTT's bankruptcy.

\section{INSERT FIGURE 1}

Table 2 presents the descriptive statistics comparing subsidiaries with their relevant industries as of December 31, 2001. Panel A presents the descriptive statistics for KMP, NBP, and EOTT versus the other firms in Enron's industry. The three subsidiaries are similar to peer firm except that the subsidiaries have relatively lower institutional ownership and book to market ratio. Panel B presents the descriptive statistics for EOG compared to its industry. EOG is

\footnotetext{
${ }^{16}$ Of course, we also observe a sharp drop around September 11, unrelated to any Enron events.

${ }^{17}$ We do not include the full year since our later test covers the sample period through the end of August 2002. In addition, EOTT's bankruptcy in October 2002 would hinder the comparison of full year data.
} 
generally much larger than the average firm and its descriptive statistics are consistent with that fact.

\section{INSERT TABLE 2}

\section{RESEARCH DESIGN AND RESULTS}

\subsection{Reaction around Enron events}

To test our first set of hypotheses (1 through $2 \mathrm{~d}$ ), we examine cumulative abnormal returns (CARs) within 11-day trading windows (+/- 5 days) around each Enron event. ${ }^{18} \mathrm{We}$ calculate CARs with a market model using the value-weighted market index and an estimation window of 220 days, beginning 40 days prior to the first Enron event. As illustrated in Panel B of Table 1, we center our first event, related to Enron's acknowledgment of potential accounting issues, on October 22, 2001. This is the date Enron acknowledged the SEC inquiry into offbalance sheet accounting. This window captures October 16, 2001, which is the first date that Enron announced the existence of accounting errors. The second window centers on Enron's restatement announcement date, November 8, 2001, and the third window centers on Enron's bankruptcy announcement date of December 2, 2001. These event windows do not overlap.

We test our first hypothesis examining the industry-wide reaction, measured using CAR, to each of the three Enron announcements. Consistent with our expectations and with prior literature, Table 3 shows that the firms in Enron's industry experience a negative market reaction to each of the three major events: Enron's acknowledgement of accounting issues (-1.65\%, p-

\footnotetext{
${ }^{18}$ Our results are robust to following the Schipper and Thompson (1983) method to adjust for the fact that each event affects all firms on the same day. Our results are also robust to using a "buy and hold" abnormal return from October 15, 2001 to December 6, 2001 rather than examining each event date separately.
} 
value $=0.1607)$, Enron's restatement announcement $(-3.04 \%$, p-value $=0.0821)$, and Enron's

bankruptcy announcement $(-4.06 \%, \mathrm{p}$-value $=0.0105) .{ }^{19}$

\section{INSERT TABLE 3}

We next turn to our main hypotheses testing for differential reactions between the industry and Enron's subsidiaries. Hypotheses 2a, b, c, and d focus on the market reactions to KMP (limited ties to Enron), NBP (control, where Enron performs the accounting tasks), EOTT (control, where Enron performs the accounting tasks, plus economic ties), and EOG (outside of Enron's industry) around the three event dates, respectively. We expect that the market can identify the relevant connections between each subsidiary and Enron, and reacts accordingly. Specifically, we predict that NBP and EOTT experience more negative market reactions around the Enron events compared to other firms in their industry given the accounting and economic connections to Enron, whereas we expect the market reaction to KMP and EOG to be in line with their industries given their weaker connections to Enron.

Panel A of Table 4 presents the market response to KMP, a subsidiary with limited ties to Enron. Consistent with the null hypothesis $2 \mathrm{a}$, we find no differential market reaction to KMP than to the industry. This finding suggests that a subsidiary with limited ties to the failing firm draws no additional market reaction, despite any previous managerial links. That is, in contrast to prior research suggesting that managers suffer from being associated with a firm with a prior accounting scandal regardless of the managers' involvement in the scandal (e.g., Groysberg et al. 2016), the firm does not appear to suffer from being associated with a manager of a firm with a prior scandal. This also differs from Nam et al. (2018) who find that the current firm suffers

\footnotetext{
${ }^{19}$ We exclude EOG and EOG's industry and focus only on Enron's main industry in this analysis. In an additional test, we drop Enron's subsidiaries in the sample and repeat our analysis. The negative reaction around second event (announcement of restatement) becomes insignificant, suggesting the market reaction to subsidiaries contributes to the significant result for that event date presented in Table 3.
} 
negative consequences when the manager is revealed to be of lower quality based on events connected to the manager at the manger's former firm. Panel B of Table 4 presents the market response to NBP, the subsidiary controlled by Enron and where Enron performs the accounting tasks. Contrary to our prediction in hypothesis $2 \mathrm{~b}$, although NBP has negative CARs around the three major events, there is no significant difference in market reaction between NBP and other firms in its industry. This result is surprising; given that Enron was an accounting scandal, the lack of market reaction to a subsidiary where Enron controlled the accounting is puzzling.

Panel C of Table 4 presents the market reaction to EOTT, the subsidiary not only controlled by Enron, where Enron performs the accounting, but also with strong economic ties to Enron. Again, contrary to our hypothesis 2c, we do not find the market reacts more negatively to EOTT compared to other firms in its industry. As with the results related to hypothesis $2 \mathrm{~b}$, the lack of reaction to EOTT, including around the bankruptcy announcement, where Enron controls the accounting and economically supports the entity is quite surprising. We acknowledge that our sample is small making statistical power a concern. However, around Enron's bankruptcy announcement, which all but assured EOTT's demise as discussed earlier, power is not an issue because EOTT's return is actually less negative than the industry average.

Finally, Panel D of Table 4 examines the market reaction to EOG, the subsidiary outside of Enron's industry. As expected, we find no difference in the market reaction for EOG as compared to other firms in its industry. Overall, both the subsidiaries and the industry have negative CARs, but they are not significantly different from each other. ${ }^{20}$ Results imply that the market reacts to industry-wide news, but has difficulty incorporating the firm-specific portion of that news into firms most likely to be affected, possibly due to limited attention.

\footnotetext{
${ }^{20}$ Our Table 4 results are robust to using a 3-day window instead of an 11-day window, except EOTT's return is marginally negative $(p$-value $=0.060)$ around the October 22 event (acknowledgement of SEC inquiry).
} 


\section{INSERT TABLE 4}

\subsection{Reaction following Enron events}

So far, we have focused on investors' ability to react differently to Enron's subsidiaries based on each subsidiaries' specific ties to Enron, and the results suggest that market does not reacts differently to the subsidiaries most connected to Enron around the three major Enron events compared to the industry. However, the market may be slow to recognize news. Therefore, we further investigate the market reaction to the most connected subsidiaries (NBP and EOTT) versus the rest of their industry over the six months following the end of the news related to the Enron scandal. ${ }^{21}$ In addition to the market returns we examine above, we also use accounting returns to investigate if NBP and EOTT underperform the industry. We use return on assets (ROA) to measure firms' performance and examine the ROA of NBP and EOTT in the last quarter of 2001 and over the year of 2002. These tests allow us to determine if the most connected subsidiaries (NBP and EOTT) actually suffer from Enron's failure. If they do not, it indicates that the lack of market reaction to the Enron events is appropriate.

\section{INSERT TABLE 5}

As shown in Panel A of Table 5, there is no significant difference in market reaction between NBP and the rest of the industry over the six months after the Enron scandal. Interestingly, Panel B and Panel C of Table 5 shows that NBP performed in line with the industry both in the last quarter of 2001 and in the following year. This result is inconsistent with hypothesis 3 a predicting that a subsidiary controlled by the failing parent, and where the parent performs the accounting tasks, will have lower future performance than its industry peers. We propose two possible explanations for this lack of results. On one hand, results could indicate

\footnotetext{
21 3/1/2002 to 8/31/2002, based on the last scandal date from Chaney and Philipich (2002).
} 
that investors successfully discern that the accounting issues specific to Enron are unlikely to have an impact on NBP, despite the fact that it shares accounting team with Enron. On the other hand, results could indicate that investors were unaware of the parent-subsidiary connections.

Turning to test on EOTT, Panel A of Table 6 shows that EOTT had significant negative abnormal returns over the six months after the Enron events. Although Panel B of Table 6 shows that EOTT did not perform significantly worse than the industry in the fourth quarter of 2001, the fact that EOTT ultimately filed for bankruptcy on October 23, 2002 (preventing our analysis of the full year 2002) supports our prediction in hypothesis $3 \mathrm{~b}$ that a subsidiary having strong economic ties with its failing parent will have lower future performance than its industry peers. Overall, results from Table 6 imply that it takes time for investors to recognize strong economic ties between EOTT and Enron and react accordingly.

In sum, our tests suggest that the market is slow in identifying affiliated firms who are most likely to suffer from parent firms' failure but instead penalizes a broader class of firms, such as firms in the same industry. Overall, our results are consistent with an underreaction to highly relevant firm-specific intra-industry information.

\section{INSERT TABLE 6}

To glean additional insight into how the failure of Enron could affect its subsidiaries, we extend the financial performance analysis (measured by ROA) over the five quarters starting from the quarter of the bankruptcy event, and over the full years of 2001 and 2002. We perform this analysis to see if the subsidiaries suffer from Enron's failure to different degrees based on their involvement with Enron's business. Specifically, we investigate the performance of KMP (limited ties) and NBP (control only, where Enron performs accounting tasks) combined, and EOG (outside of Enron's industry) relative to their industry firms. We exclude EOTT because of 
its bankruptcy. Panel A of Table 7 shows that KMP and NBP perform in line with the industry over the five quarters and the year 2001 and 2002. ${ }^{22}$ Panel B of Table 7 shows that EOG also performs in line with its industry. Overall, the results suggest that subsidiaries not economically tied to the failing firm are unlikely to suffer economic consequences from the failure. In addition, it provides an explanation for our finding that the market does not react differently to those subsidiaries around parent's failure.

\section{INSERT TABLE 7}

\subsection{Potential mechanisms behind the lack of immediate reaction to the Enron events}

To further explore the possible reasons behind the lack of market reaction upon Enron's restatement and bankruptcy, we examine institutional ownership and analyst following. Low investor sophistication or low analyst coverage could explain the failure of investors to identify subsidiaries that had accounting/managerial and/or economic connections to the parent. Therefore, we investigate if the subsidiaries have different level of institutional ownership (analyst coverage) than other firms in their industry, and compare the market reaction to the subsidiaries versus to other firms in the same group. We obtain institutional ownership (analyst following) data from Thomson Reuters (IBES). Using the median of institutional ownership and analyst following as the cutoff, we divide our sample into high/low institutional ownership (analyst coverage). We find a significantly negative reaction to Enron events only among industry peers with above-median institutional ownership (Table 8, Panel A and C). ${ }^{23}$ The three Enron subsidiaries in its industry (NBP, EOTT, KMP) all have below-median institutional ownership, suggesting the absence of informed investors as a reason behind the unexpected lack of results in our main market reaction tests for the subsidiaries. We find no difference in reaction

\footnotetext{
${ }^{22}$ Results are unchanged if we separately test KMP (NBP) relative to its industry.

${ }^{23} \mathrm{We}$ acknowledge that we only find limited evidence here, as our small sample tests have relatively low power.
} 
between the three subsidiaries and the industry in the low institutional ownership group (Table 8 , Panel B). When testing market reaction after splitting the sample by analyst coverage, we find that all the subsidiaries (KMP, NBP, and EOTT) have high analyst coverage. However, as shown in Table 9, we do not find a significant difference in market reaction between peer firms with high versus low analyst coverage (Table 9, Panel C) or between subsidiaries and peer firms with high analyst coverage (Table 9, Panel A).

\section{INSERT TABLE 8}

\section{INSERT TABLE 9}

To further investigate the lack of differential reaction based on analyst following, we look into the timeliness and frequency of the annual analysts' forecasts for 2001. Despite the existence of coverage, subsidiaries with inactive analysts may have relatively weak information environments, which may partially drive market underreaction. We measure the timeliness of analyst forecasts by counting days between the IBES summary date immediately before the first Enron event (10/15/2001) and the next 2001 annual analyst forecast for each analyst for each subsidiary, and we measure the frequency of analysts' forecasts by calculating the average number of annual analyst forecasts made by analysts over 2001. Panel A of Table 10 shows that, on average, analysts following KMP and EOG issue their an annual forecast 18 days after the first Enron event. However, it took longer for analysts following NBP and EOTT to issue their next annual forecasts. Specifically, on average, analysts following NBP (EOTT) took 26.75 (49) days to issue their next 2001 annual forecast after the first Enron event. While the quickest analyst for KMP, NBP, and EOG all released a forecast within 10 days of the IBES summary date immediately before the Enron events (i.e., around the time of the first Enron event), the fastest analyst for EOTT took 30 days. These results suggest that a particularly weak information 
environment could be responsible for EOTT's lack of market reaction upon Enron's bankruptcy. However, we note that EOTT's analysts forecast relatively frequently, even though they appear to issue slowly (Table 10, Panel B).

\section{INSERT TABLE 10}

Lastly, we compare market reactions to Enron's subsidiaries versus industry firms that are likely to suffer restatement/bankruptcy in the future period. We identify these firms using actual restatements and bankruptcies. We expect that those industry firms that restate or go bankrupt soon after Enron's failure may have similar characteristics with Enron's subsidiaries especially EOTT which eventually went bankrupt - and the market should react similarly to those restating/bankrupt firms compared to the subsidiaries. Panel A of Table 11 shows that we find no significant difference in market reaction between subsidiaries and restating/bankrupt firms around the three Enron's events. Since EOTT is the only subsidiary that went bankrupt in the later period, we separately compare EOTT relative to the restating/bankrupt firms in the same industry. Panel $\mathrm{C}$ of Table 11 continues to show no significant difference in market reaction between EOTT and restating/bankrupt firms in the same industry. These results rule out the possibility that the market underreaction is driven by some unique characteristics of the subsidiaries compared to other industry firms who also suffer the most from Enron's failure.

\section{INSERT TABLE 11}

\section{CONCLUSION}

In this study, we explore the information transfer between parents and subsidiaries after considering the various connections between these firms. Using Enron as our unique setting, we empirically examine the market reaction to subsidiaries with managerial/accounting (i.e., 
reputational) and/or economic connections to a parent firm when the parent firm undergoes a high profile restatement and bankruptcy. We fail to find evidence of incremental market reaction to subsidiaries around the three Enron events, regardless of the subsidiaries connections to Enron. Over the year following the Enron events, the subsidiary where Enron controlled the accounting but with little economic ties performed in-line with the industry, consistent with the lack of incremental market reaction to this firm versus the industry. However, the subsidiary sharing strong economic ties to Enron experiences a significant negative market reaction over the six months after the Enron event, with this subsidiary going bankrupt. This suggests market underreaction to this subsidiary around the Enron events. This could arise from limited attention that prevents investors from identifying specific connections relevant to the parent's failure, and instead, causes them to focus on the broad, industry-wide implications of parent's failure. Additional results indicate that low institutional ownership or slow analyst forecast updates could explain this market under-reaction. Overall, results suggest that the market fails to immediately incorporate the information on the reputational and/or economic relationships between failing parent and subsidiaries into market prices.

This study provides insights as to whether managerial reputation or economic ties impact subsidiaries market prices around a restatement (bankruptcy) of a parent firm. Our study contributes to the literature related to the contagion and peer effects of restatements and bankruptcy. Our findings suggest the market has difficulty identifying parent-subsidiary connections and that a weak information environment may play a role in this. As such, our study has implications for academics, regulators, and investors who are interested in examining information transfer effects to small firms. 


\section{REFERENCES}

Acharya, V. V., O. F. Gottschalg, M. Hahn, and C. Kehoe. 2013. Corporate governance and value creation: Evidence from private equity. Review of Financial Studies 26 (2): 368402.

Addoum, J. M., A. Kumar, N. Le, and A. Niessen-Ruenzi. 2019. Local bankruptcy and geographic contagion in the bank loan market. Review of Finance forthcoming.

Atiase, R. K. 1985. Predisclosure information, firm capitalization, and security price behavior around earnings announcements. Journal of Accounting Research 23 (1): 21-36.

Ayers, B., and R. Freeman. 2003. Evidence that analyst following and institutional ownership accelerate the pricing of future earnings. Review of Accounting Studies 8 (1): 47-67.

Bae, G. S., Y. S. Cheon, and J.-K. Kang. 2008. Intragroup propping: Evidence from the stockprice effects of earnings announcements by Korean business groups. Review of Financial Studies 21 (5): 2015-2060.

Badertscher, B. A., S. P. Katz, and S. O. Rego. 2013. The separation of ownership and control and corporate tax avoidance. Journal of Accounting and Economics 56: 228-250.

Baginski, S. P. 1987. Intraindustry information transfers associated with management forecasts of earnings. Journal of Accounting Research 25 (2): 196-216.

Baugh, M., J. P. Boone, I. K. Khurana, and K.K. Raman. 2019. Did the 2005 deferred prosecution agreement adversely affect KPMG's audit practice? Auditing: A Journal of Practice and Theory 38 (1): 77-102.

Beatty, A., S. Liao, and J. J. Yu. 2013. The spillover effect of fraudulent financial reporting on peer firms' investments. Journal of Accounting and Economics 55: 183-205.

Beaver, W. H., S. Cascino, M. Correia, and M. F. McNichols. 2019. Group affiliation and default prediction. Management Science forthcoming.

Benmelech, E., N. Bergman, A. Milanez, and V. Mukharlyamov. 2018. The agglomeration of bankruptcy. Review of Financial Studies forthcoming.

Benston, G. J., and A. L. Hartgraves. 2002. Enron: What happened and what we can learn from it. Journal of Accounting and Public Policy 21: 105-127.

Bernile, G., and E. Lyandres. 2019. The effects of horizontal merger operating efficiencies on rivals, customers, and suppliers. Review of Finance 23 (1): 117-160.

Blouin, J., B. M. Grein, and B. R. Rountree. 2007 An analysis of forced auditor change: The case of former Arthur Andersen clients. The Accounting Review 82: 621-650. 
Bonacchi, M., F. Cipollini, and P. Zarowin. 2018. Parents' use of subsidiaries to "push down" earnings management: Evidence from Italy. Contemporary Accounting Research 35 (3): $1332-1362$.

Bonacchi, M., A. Marra, and P. Zarowin. 2019. Earnings quality of private and public firms: Business groups versus stand-alone firms. Review of Accounting Studies 24: 1066-1113.

Boone, A. L., and V. I. Ivanov. 2012. Bankruptcy spillover effects on strategic alliance partners. Journal of Financial Economics 103: 551-569.

Brochet, F., K. Kolev, and A. Lerman. 2016. Information transfer and conference calls. Review of Accounting Studies 23: 907-957.

Brown, S. V., X. S. Tian, and J. W. Tucker. 2018. The spillover effects of SEC comment letters on qualitative corporate disclosure: Evidence from the risk factor disclosure. Contemporary Accounting Research 35 (2): 622-656.

Bushee, B. J. 1998. The influence of institutional investors on myopic R\&D investment behavior. The Accounting Review 73 (3): 305-333.

Cao, S. S., Y. Fan, G. S. Narayanamoorthy, and S. P. Rowe. 2018. Auditor litigation: Consequences for other auditors. Working paper, Georgia State University.

Chaney, P. K., and K. L. Philipich. 2002. Shredded reputation: The cost of audit failure. Journal of Accounting Research 40 (4): 1221-1245.

Chen, S., B. Miao, and K. Valentine. 2018. The market for corporate control and information quality: Evidence from peer firm disclosure response to takeover threat. Working paper.

Christensen, H. B. 2019. Broad- versus narrow-sample evidence in disclosure regulation studies: A discussion of Badia, Duro, Jorgensen, and Ormazabal. Contemporary Accounting Research forthcoming.

Cohn, J. B., L. F. Mills, and E. M. Towery. 2014. The evolution of capital structure and operating performance after leveraged buyouts: Evidence from U.S. corporate tax returns. Journal of Financial Economics 111: 469-494.

Cornelli, F., and O. Karakaş. 2015. CEO turnover in LBOs: The role of boards. Working paper.

Creswell, J. 2003. The Anti-Enron. Fortune November 24.

Décaire, P. H., E. P. Gilje, and J. P. Taillard. 2019. Real option exercise: Empirical Evidence. Working paper.

Dee, C. C., A. Lulseged, and T. Zhang. 2011. Client stock market reaction to PCAOB sanctions against a Big 4 auditor. Contemporary Accounting Research 28 (1): 263-291.

DellaVigna, S., and J. M. Pollet. 2009. Investor inattention and Friday earnings announcements. The Journal of Finance 64 (2): 709-749. 
Deller, C., and T. Sandino. 2019. Effects of a tournament incentive plan incorporating managerial discretion in a geographically dispersed organization. Management Science forthcoming.

Desai, H., C. E. Hogan, and M. S. Wilkins. 2006. The reputational penalty for aggressive accounting: Earnings restatements and management turnover. The Accounting Review 81 (1): 83-112.

Dessaint, O., T. Foucault, L. Frésard, and A. Matray. 2018. Noisy stock prices and corporate investment. Review of Financial Studies forthcoming.

Donelson, D. C., M. Ege, and J. Leiby. 2019. Audit firm reputational consequences of alleged non-accounting misconduct by clients: How bargaining power temporarily shifts around securities litigation. Auditing: A Journal of Practice and Theory 38 (4): 77-100.

Dyreng, S. D., M. Hanlon, and E. L. Maydew. 2012. Where do firms manage earnings? Review of Accounting Studies 17: 649-687.

Eliason, P. J., B. Heebsh, R. C. McDevitt, and J. W. Roberts. 2020. How acquisitions affect firm behavior and performance: Evidence from the dialysis industry. The Quarterly Journal of Economics 135 (1): 221-267.

Fee, C. E., C. J. Hadlock, and J. R. Pierce. 2013. Managers with and without style: Evidence using exogenous variation. Review of Financial Studies 26 (3): 567-601.

Fich, E. M., and A. Shivdasani. 2007. Financial fraud, director reputation, and shareholder wealth. Journal of Financial Economics 86: 306-336.

Firth, M. 1976. The impact of earnings announcements on the share price behaviour of similar type firms. The Economic Journal 86 (342): 296-306.

Firth, M. 1996. Dividend changes, abnormal return, and intra-industry firm valuations. Journal of Financial and Quantitative Analysis 31 (2): 189-211.

Foucault, T., and L. Fresard. 2014. Learning from peers' stock prices and corporate investment. Journal of Financial Economics 111: 554-577.

Foster, G. 1981. Intra-industry information transfers associated with earnings releases. Journal of Accounting and Economics 3 (3): 201-232.

Fu, R. 2016. Insider trading filing and intra-industry information transfer. Working paper, Shanghai Jiaotong University.

Gangloff, K. A., B. L. Connelly, and C. L. Shook. 2016. Of scapegoats and signals: Investor reactions to CEO succession in the aftermath of wrongdoing. Journal of Management 42 (6): 1614-1634. 
Gantchev, N., O. R. Gredil, and C. Jotikasthira. 2018. Governance under the gun: Spillover effects of hedge fund activism. Review of Finance forthcoming.

Ginglinger, E., C. Hebert, and L. Renneboog. 2018. Are investors aware of ownership connections? Working paper.

Gleason, C. A., N. T. Jenkins, and W. B. Johnson. 2008. The contagion effects of accounting restatements. The Accounting Review 83 (1): 83-110.

Goktan, M. S., and V. Muslu. 2018. Benefits of public reporting: Evidence from IPOs backed by listed private equity firms. Journal of Corporate Finance 50: 669-688.

Groysberg, B., E. Lin, G. Serafeim, and R. Abrahams. 2016. The scandal effect. Harvard Business Review September: 90-98

Gul, F. A., C. Y. Lim, K. Wang, and Y. Xu. 2019. Stock price contagion effects of low-quality audits at the individual partner level. Auditing: A Journal of Practice and Theory 38 (2): 151-178.

Guo, F., T. R. Kubick, and A. Masli. 2018. The effects of restatements for misreporting on auditor scrutiny of peer firms. Accounting Horizons 32 (1): 65-85.

Grennan, J. 2018. Dividend payments as a response to peer influence. Journal of Financial Economics forthcoming.

Hellmann, T., and M. Puri. 2002. Venture capital and the professionalization of start-up firms: Empirical evidence. The Journal of Finance 57 (1): 169-197.

Hertzel, M., Z. Li, M. S. Officer, and K. J. Rodgers. 2008. Inter-firm linkages and the wealth effects of financial distress along the supply chain. Journal of Financial Economics 87: 374-387.

Hertzel, M., and M. S. Officer. 2012. Industry contagion in loan spreads. Journal of Financial Economics 103: 493-506.

Hirshleifer, D., and S. H. Teoh. 2003. Limited attention, information disclosure, and financial reporting. Journal of Accounting and Economics 36: 337-386.

Hirshleifer, D., S. S. Lim, and S. H. Teoh. 2009. Driven to distraction: Extraneous events and underreaction to earnings news. The Journal of Finance 64 (5): 2289-2325.

Hoffman, M., L. B. Kahn, and D. Li. 2018. Discretion in hiring. Quarterly Journal of Economics 133 (2): 765-800.

Hope, O.-K., and W. Zhao. 2016. Market reactions to the closest peer firm's analyst revisions. Working paper, University of Toronto. 
Jia, W., and J. Zhao. 2016. Does the market punish the many for the sins of the few? The contagion effect of accounting restatements for foreign firms listed in the U.S. Working paper, Emory University.

Joe, D. Y., and F. D. Oh. 2018. Spillover effects within business groups: The case of Korean chaebols. Management Science 64 (3): 1396-1412.

Kaplan, S. 1989. The effect of management buyouts on operating performance and value. Journal of Financial Economics 24: 217-254.

Karpoff, J. M., D. S. Lee, and G. S. Martin. 2008a. The consequences to mangers for financial misrepresentation. Journal of Financial Economics 88: 193-215.

Karpoff, J. M., D. S. Lee, and G. S. Martin. 2008b. The cost to firms of cooking the books. Journal of Financial and Quantitative Analysis 43 (3): 581-612.

Katz, S. P. 2009. Earnings quality and ownership structure: The role of private equity sponsors. The Accounting Review 84 (3): 623-658.

Kaustia, M., and V. Rantala. 2015. Social learning and corporate peer effects. Journal of Financial Economics 117: 653-669.

Kedia, S., K. Koh, and S. Rajgopal. 2015. Evidence on contagion in earnings management. The Accounting Review 90 (6): 2337-2373.

Ko, M. 2018. Family names of firms help investors pay attention to the family. Working paper.

Kravet, T., and T. Shevlin. 2010. Accounting restatements and information risk. Review of Accounting Studies 15 (2): 264-294.

Lamont, O. A., and R. H. Thaler. 2003. Can the market add and subtract? Mispricing in tech stock carve-outs. Journal of Political Economy 111 (2): 227-268.

Lang, L. H. P., and R. M. Stulz. 1992. Contagion and competitive intra-industry effects of bankruptcy announcements: An empirical analysis. Journal of Financial Economics 32 (1): 45-60.

Larrain, B., G. Sertsios, and F. Urzúa. 2019. The effects of losing a business group affiliation. Review of Financial Studies 32 (8): 3036-3074.

le Bris, D., W. N. Goetzmann, and S. Pouget. 2019. The present value relation over six centuries: The case of the Bazacle company. Journal of Financial Economics 132: 248-265.

Lee, C. M. C., S. T. Sun, R. Wang, and R. Zhang. 2019. Technological links and predictable returns. Journal of Financial Economics 132: 76-96.

Legoria, J., K. J. Reichelt, and J. S. Soileau. 2018. Auditors and disclosure quality: The case of major customer disclosures. Auditing: A Journal of Practice and Theory 37 (3): 163-189. 
Li, V. 2016. Do false financial statements distort peer firms' decisions? The Accounting Review 91 (1): 251-278.

Mason, P., and S. Utke. 2019. The structure of private funds, their relation to private firms, and the implications for accounting, economics, and finance research. Working paper.

McDonnell, M.-H., and E. Pontikes. 2018. Bad company: Tactics, stigma, and shifts in public approval of environmental activist organizations after the BP oil spill. Working paper.

McGill, G. A., and E. Outslay. 2002. Did Enron pay taxes? Using accounting information to decipher tax status. Tax Notes 96 (8) (August 19, 2002): 1125-1136.

McNichols, M. F. 2000. Research design issues in earnings management studies. Journal of Accounting and Public Policy 19: 313-345.

Morningstar. 2019. Benefits of MLPs. Course 503: Unconventional Equities.

Morsfield, S. G., and C. E. L. Tan. 2006. Do venture capitalists influence the decision to manage earnings in initial public offerings? The Accounting Review 81 (5): 1119-1150.

Nelson, K. K., R. A. Price, and B. R. Rountree. 2008. The market reaction to Arthur Andersen's role in the Enron scandal: Loss of reputation or confounding effects? Journal of Accounting and Economics 46: 279-293.

Ramnath, S. 2002. Investor and analyst reactions to earnings announcements of related firms: An empirical analysis. Journal of Accounting Research 40 (5): 1351-1376.

Schipper, K., and R. Thompson. 1983. The impact of merger-related regulations on the shareholders of acquiring firms. Journal of Accounting Research 21 (1): 184-221.

Shaw, W. H., and H. A. Wier. 1993. Organizational form choice and the valuation of oil and gas producers. The Accounting Review 68 (3): 657-667.

Silvers, R. 2016. The valuation impact of SEC enforcement actions on nontarget foreign firms. Journal of Accounting Research 54 (1): 187-233.

Street, D. A., and D. R. Hermanson. 2019. How do restatements affect outside directors and boards? A review of the literature. Journal of Accounting Literature 43: 19-46.

Thomas, J., and F. Zhang. 2008. Overreaction to intra-industry information transfers? Journal of Accounting Research 46 (4): 909-940.

Weber, J., M. Willenborg, and J. Zhang. 2008. Does auditor reputation mater? The case of KPMG Germany and ComROAD AG. Journal of Accounting Research 46 (4): 941-972. 
FIGURE 1

Cumulative Return Trends for Subsidiaries and Industry

This figure presents the cumulative return trends for KMP, NBP, and EOTT versus Enron's industry from January 2001 to August 2002 (we do not include EOG since it is outside Enron's industry). Panel A (B) compares cumulative returns for the three subsidiaries and the industry from January to June 2001 (July to December 2001). To enable better comparison between the two groups, we reset the cumulative returns at the beginning of July for Panel B. Panel C compares cumulative returns for the three subsidiaries and the industry from January to August 2002. We do not include the full year since our main test covers sample period until the end of August 2002, in addition, EOTT's bankruptcy in October 2002 would hinder the comparison.

Panel A: Cumulative Return: Subsidiaries versus Industry (January 2001 - June 2001)

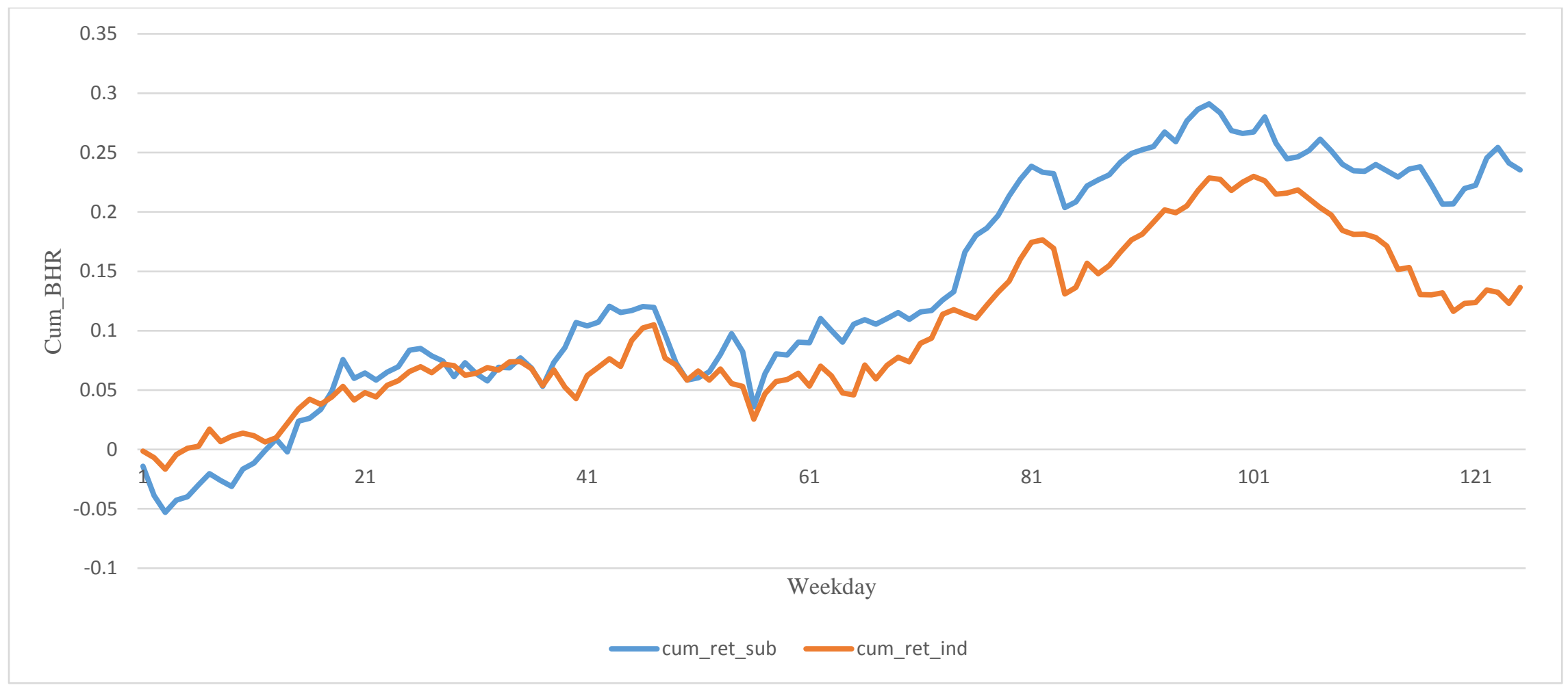


FIGURE 1 (Continued)

Cumulative Return Trends for Subsidiaries and Industry

Panel B: Cumulative Return: Subsidiaries versus Industry (July 2001 - December 2001)

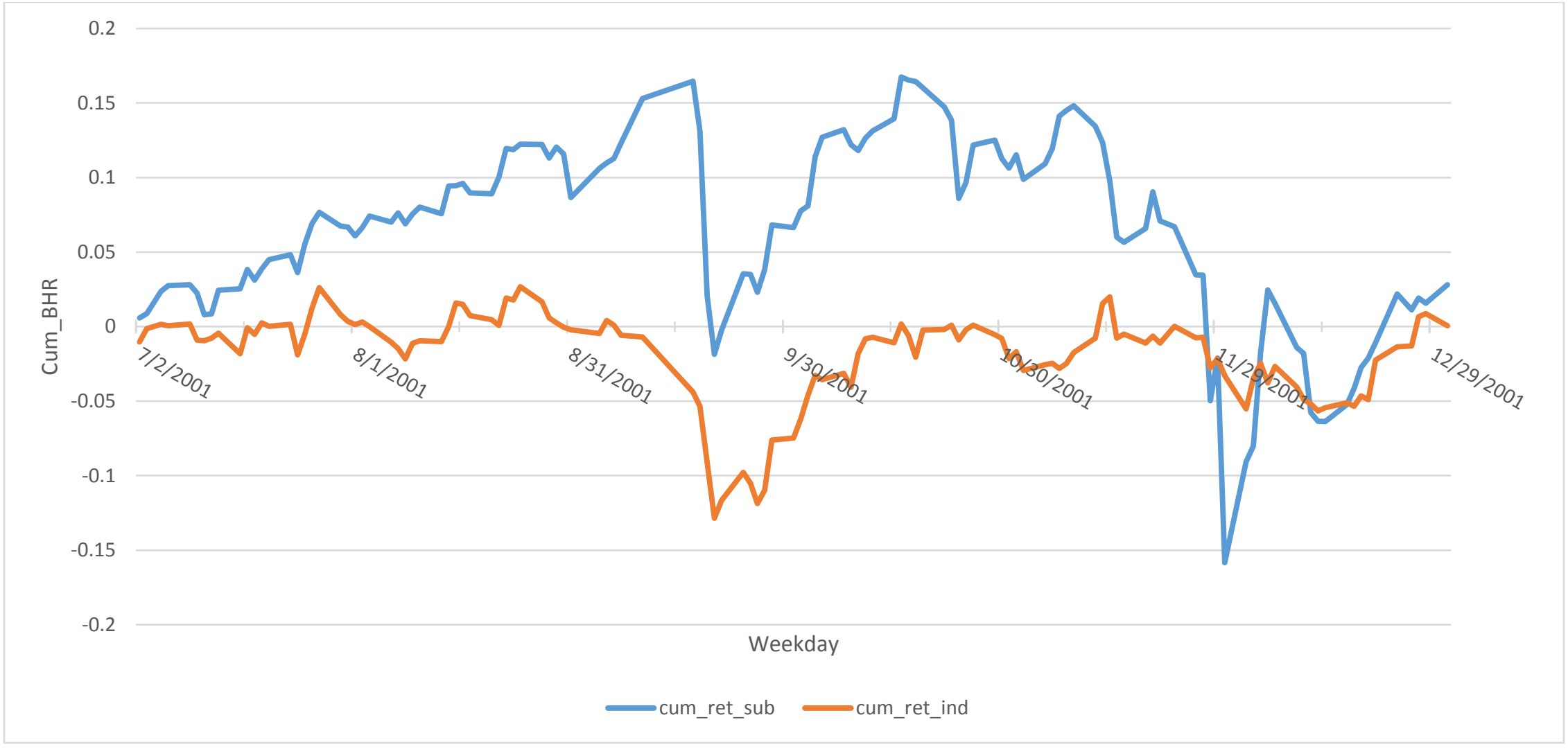


FIGURE 1 (Continued)

Cumulative Return Trends for Subsidiaries and Industry

Panel C: Cumulative Return: Subsidiaries versus Industry (January 2002 - August 2002)

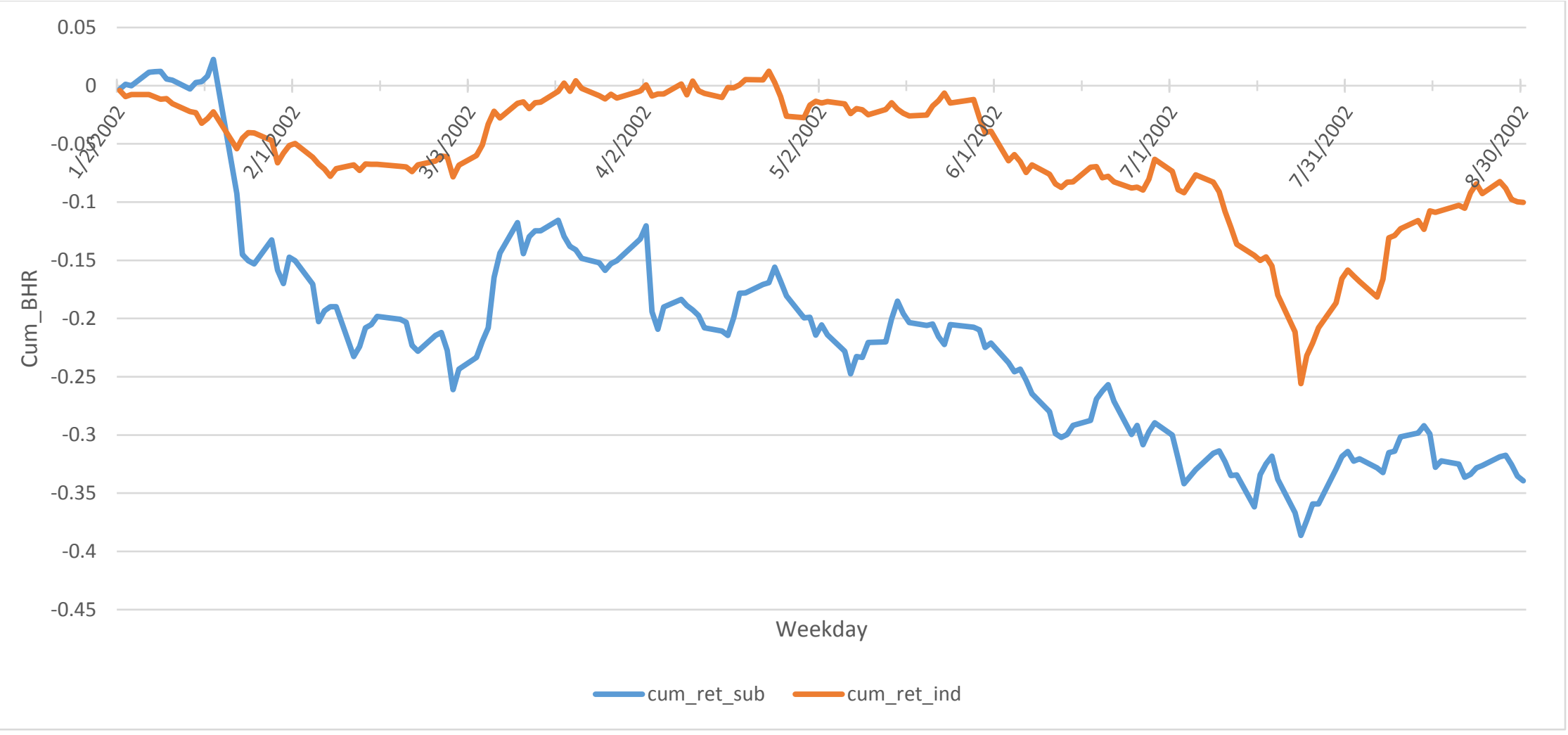




\section{TABLE 1 \\ Setting and Sample Selection}

This table provides a brief description of Enron's subsidiaries (Panel A). Panel B briefly lists the relevant Enron events studied in the paper. Panel $\mathrm{C}$ details the sample selection process. The industries we consider are SICs: 5172, 5171, 1311, 1321, 1381, 4610, 4612, 4613, 4619, 4922, 4923.

Panel A: Enron's (Former) Subsidiaries

\begin{tabular}{|c|c|c|}
\hline $\begin{array}{l}\text { Subsidiary } \\
\text { Name }\end{array}$ & Abbreviation & Connection to Enron \\
\hline $\begin{array}{l}\text { Kinder } \\
\text { Morgan } \\
\text { Energy } \\
\text { Partners }\end{array}$ & KMP & $\begin{array}{l}\text { A subsidiary with limited ties with Enron. At the time of } \\
\text { Enron's failure, this entity's main connection to Enron was } \\
\text { through its managers' prior work experience at Enron. }\end{array}$ \\
\hline $\begin{array}{l}\text { Northern } \\
\text { Border } \\
\text { Partners }\end{array}$ & NBP & $\begin{array}{l}\text { A subsidiary controlled by Enron, where Enron was } \\
\text { responsible for performing NBP's accounting tasks. This entity } \\
\text { was later known as ONEOK Partners. }\end{array}$ \\
\hline $\begin{array}{l}\text { EOTT } \\
\text { Energy }\end{array}$ & EOTT & $\begin{array}{l}\text { A subsidiary not only controlled by Enron but also having } \\
\text { close economic ties with Enron, where Enron also controlled } \\
\text { the accounting. }\end{array}$ \\
\hline $\begin{array}{l}\text { EOG } \\
\text { Resources }\end{array}$ & $\mathrm{EOG}$ & $\begin{array}{l}\text { A subsidiary outside of Enron's industry. At the time of } \\
\text { Enron's failure, Enron's main remaining connection to this } \\
\text { entity was a } 9.2 \% \text { equity interest. }\end{array}$ \\
\hline
\end{tabular}

Panel B: Enron Events

\begin{tabular}{lll}
\hline Event Dates & Event Name & Description \\
\hline $10 / 22 / 2001$ & $\begin{array}{l}\text { Acknowledgement } \\
\text { of Issues/SEC } \\
\text { Inquiry }\end{array}$ & Enron announced potential accounting issues \\
$11 / 08 / 2001$ & Restatement & $\begin{array}{l}\text { Enron announced its plan to restate its reported net income } \\
\text { for the years 1997-2002 }\end{array}$ \\
$12 / 02 / 2001$ & Bankruptcy & $\begin{array}{l}\text { Enron filed for bankruptcy under Chapter } 11 \text { of the United } \\
\text { States Bankruptcy Code }\end{array}$ \\
\hline
\end{tabular}


TABLE 1 (Continued)

Setting and Sample Selection

Panel C: Sample selection

\begin{tabular}{|c|c|c|c|c|}
\hline & $10 / 22 / 2001$ & $11 / 08 / 2001$ & $12 / 02 / 2001$ & $\begin{array}{l}03 / 01 / 2002- \\
08 / 31 / 2002 \\
\end{array}$ \\
\hline & $\begin{array}{l}\text { Acknowledgement } \\
\text { of Issues }\end{array}$ & Restatement & Bankruptcy & $\begin{array}{c}\text { Subsequent } 6 \\
\text { months }\end{array}$ \\
\hline $\begin{array}{l}\text { Merged Compustat } \\
\text { and CRSP } \\
\text { Observations in } \\
\text { Relevant Industries }\end{array}$ & 300 & 316 & 314 & 491 \\
\hline Less: & & & & \\
\hline $\begin{array}{l}\text { Observations not } \\
\text { Qualifying 11- } \\
\text { day Trading } \\
\text { Windows }\end{array}$ & (123) & (140) & (139) & (315) \\
\hline Enron & (1) & (1) & (1) & $\mathrm{n} / \mathrm{a}$ \\
\hline Full Sample & & & & \\
\hline $\begin{array}{l}\text { (Comprised of firms } \\
\text { within the same } \\
\text { industry as Enron or } \\
\text { EOG) }\end{array}$ & 176 & 175 & 174 & 176 \\
\hline $\begin{array}{l}\text { Enron Industry } \\
\text { (including } \\
\text { subsidiaries) }\end{array}$ & 37 & 37 & 37 & 40 \\
\hline $\begin{array}{c}\text { EOG Industry } \\
\text { (including EOG) }\end{array}$ & 139 & 138 & 137 & 136 \\
\hline
\end{tabular}


TABLE 2

\section{Descriptive Statistics}

This table presents the descriptive statistics for subsidiaries versus their relevant industry firms. Panel A compares KMP, NBP, and EOTT with Enron's industry. Panel B compares EOG with other firms in its industry. The variables we consider are institutional ownership, analyst coverage, market value, leverage, return on asset, and book to market ratio.

Panel A: Descriptive Statistics for KMP, NBP, and EOTT versus the Industry as of December 31, 2001

\begin{tabular}{lcccc}
\hline & \multicolumn{2}{c}{ Enron's Industry } & \multicolumn{2}{c}{ Subsidiaries } \\
Variable: & $\mathrm{N}$ & Mean & $\mathrm{N}$ & Mean \\
\hline Institutional Ownership & 35 & 0.325133 & 3 & 0.117408 \\
Analyst Coverage & 35 & 10.42857 & 3 & 12 \\
Market Value & 32 & $2,849.52$ & 3 & $2,769.32$ \\
Leverage & 32 & 0.407409 & 3 & 0.428339 \\
ROA & 32 & 0.021003 & 3 & 0.028001 \\
BTM & 32 & 0.606196 & 3 & 0.386363
\end{tabular}

Panel B: Descriptive Statistics for EOG versus the Industry as of December 31, 2001

\begin{tabular}{|c|c|c|c|c|}
\hline \multirow[b]{2}{*}{ Variable: } & \multicolumn{2}{|c|}{ EOG's Industry } & \multicolumn{2}{|c|}{ EOG } \\
\hline & $\mathrm{N}$ & Mean & $\mathrm{N}$ & Mean \\
\hline Institutional Ownership & 137 & 0.35036 & 1 & 0.824115 \\
\hline Analyst Coverage & 138 & 11.76812 & 1 & 47 \\
\hline Market Value & 133 & $1,276.87$ & 1 & $4,515.33$ \\
\hline Leverage & 133 & 0.312283 & 1 & 0.25072 \\
\hline ROA & 133 & -0.00794 & 1 & 0.116758 \\
\hline ВТM & 133 & 0.663268 & 1 & 0.331118 \\
\hline
\end{tabular}




\section{TABLE 3 \\ Market Reaction to Firms in Enron's Industry}

This table presents the cumulative abnormal returns of firms in Enron's industry around each of three events. Cumulative abnormal return over an 11-day window $(-5,5)$ is calculated using the value weighted market index and an estimation window of 220 days, beginning 40 days prior to the first event. We center our first event, related to Enron's acknowledgement of potential accounting issues, on October 22, 2001. The second window is centered on the restatement announcement date, November 8, 2001, and the third window is centered on the bankruptcy announcement date of December 2, 2001. These event windows do not overlap. P values are two-tailed. $* * *, * *, *$ indicate significant differences in means for each variable across subsamples at the one percent, five percent, or ten percent level, respectively.

\begin{tabular}{lcccc}
\hline Event: & Pred. sign & $\mathrm{N}$ & $\begin{array}{c}\text { Industry Return } \\
\text { Mean } \\
\text { (Std. Dev) }\end{array}$ & P-value \\
\hline Acknowledgement & - & 37 & -0.0165 & 0.1607 \\
of issues & - & 37 & $\begin{array}{l}(0.0699) \\
-0.0304^{*}\end{array}$ & 0.0821 \\
Restatement & - & 37 & $\begin{array}{c}(0.1034) \\
-0.0406^{* *}\end{array}$ & 0.0105 \\
Bankruptcy & & & $(0.0914)$ & \\
\hline
\end{tabular}




\section{TABLE 4}

\section{Market Reaction to Enron's Subsidiaries around Event Dates}

This table presents the cumulative abnormal returns of Enron's subsidiaries versus firms in Enron's (or EOG's) industry around each of three events. Panel A examines Kinder Morgan Energy Partners (KMP), a subsidiary with limited ties with Enron. Panel B examines Northern Border Partners (NBP), a subsidiary controlled by Enron where Enron was responsible for performing the accounting tasks. Panel C examines EOTT Energy (EOTT), a subsidiary not only controlled by Enron but also having close economic ties with Enron, where Enron also controlled the accounting. Panel D examines EOG Resources (EOG), a subsidiary outside of Enron's industry where Enron's only remaining connection was an equity interest. Cumulative abnormal return over an 11-day window $(-5,5)$ is calculated using the value weighted market index and an estimation window of 220 days, beginning 40 days prior to the first event. We center our first event, related to Enron's acknowledgement of potential accounting issues, on October 22, 2001. The second window is centered on the restatement announcement date, November 8, 2001, and the third window is centered on the bankruptcy announcement date of December 2, 2001. These event windows do not overlap. P values are two-tailed. ***,**,* indicate significant differences in means for each variable across subsamples at the one percent, five percent, or ten percent level, respectively.

Panel A: Market Response to KMP around Three Event Dates

\begin{tabular}{|c|c|c|c|c|c|}
\hline Event & Pred. sign & $\begin{array}{c}\text { CAR } \\
\text { Industry } \\
\text { Mean } \\
\text { (Std. Dev) } \\
\end{array}$ & $\begin{array}{c}\text { CAR } \\
\text { KMP } \\
\text { Mean } \\
\text { (Std. Dev) } \\
\end{array}$ & Diff & P-value \\
\hline $\mathrm{N}$ : & & 34 & 1 & & \\
\hline $\begin{array}{l}\text { Acknowledgement } \\
\text { of issues }\end{array}$ & - & $\begin{array}{l}-0.0133 \\
(0.0703)\end{array}$ & $\begin{array}{c}0.0103 \\
(\mathrm{n} / \mathrm{a})\end{array}$ & 0.0236 & 0.7432 \\
\hline Restatement & - & $\begin{array}{c}-0.0244 \\
(0.1040)\end{array}$ & $\begin{array}{c}-0.1340 \\
(\mathrm{n} / \mathrm{a})\end{array}$ & -0.1095 & 0.3066 \\
\hline Bankruptcy & - & $\begin{array}{c}-0.0355^{* *} \\
(0.0879)\end{array}$ & $\begin{array}{c}0.0118 \\
(\mathrm{n} / \mathrm{a})\end{array}$ & 0.0472 & 0.5997 \\
\hline
\end{tabular}


TABLE 4 (Continued)

Market Reaction to Enron's Subsidiaries around Event Dates

Panel B: Market Response to NBP around Three Event Dates

\begin{tabular}{|c|c|c|c|c|c|}
\hline Event & Pred. sign & $\begin{array}{c}\text { CAR } \\
\text { Industry } \\
\text { Mean } \\
\text { (Std. Dev) }\end{array}$ & $\begin{array}{c}\text { CAR } \\
\text { NBP } \\
\text { Mean } \\
\text { (Std. Dev) }\end{array}$ & Diff & P-value \\
\hline $\mathrm{N}:$ & & 34 & 1 & & \\
\hline $\begin{array}{l}\text { Acknowledgement } \\
\text { of issues }\end{array}$ & - & $\begin{array}{l}-0.0133 \\
(0.0703)\end{array}$ & $\begin{array}{c}-0.0108 \\
(\mathrm{n} / \mathrm{a})\end{array}$ & 0.0025 & 0.9722 \\
\hline Restatement & - & $\begin{array}{l}-0.0244 \\
(0.1040)\end{array}$ & $\begin{array}{c}-0.0243 \\
(\mathrm{n} / \mathrm{a})\end{array}$ & 0.0001 & 0.9989 \\
\hline Bankruptcy & - & $\begin{array}{c}-0.0355^{* *} \\
(0.0879)\end{array}$ & $\begin{array}{c}-0.0200 \\
(\mathrm{n} / \mathrm{a})\end{array}$ & 0.0154 & 0.8636 \\
\hline
\end{tabular}

Panel C: Market Response to EOTT around Three Event Dates

\begin{tabular}{|c|c|c|c|c|c|}
\hline Event & Pred. sign & $\begin{array}{c}\text { CAR } \\
\text { Industry } \\
\text { Mean } \\
\text { (Std. Dev) }\end{array}$ & $\begin{array}{c}\text { CAR } \\
\text { EOTT } \\
\text { Mean } \\
\text { (Std. Dev) }\end{array}$ & Diff & $\mathrm{P}$-value \\
\hline $\mathrm{N}:$ & & 34 & 1 & & \\
\hline $\begin{array}{l}\text { Acknowledgement } \\
\text { of issues }\end{array}$ & - & $\begin{array}{l}-0.0133 \\
(0.0703)\end{array}$ & $\begin{array}{c}-0.0707 \\
(\mathrm{n} / \mathrm{a})\end{array}$ & -0.0573 & 0.4271 \\
\hline Restatement & - & $\begin{array}{l}-0.0244 \\
(0.1040)\end{array}$ & $\begin{array}{c}-0.0357 \\
(\mathrm{n} / \mathrm{a})\end{array}$ & -0.0112 & 0.9160 \\
\hline Bankruptcy & - & $\begin{array}{c}-0.0355^{* *} \\
(0.0879)\end{array}$ & $\begin{array}{c}-0.0156 \\
(\mathrm{n} / \mathrm{a})\end{array}$ & 0.0198 & 0.8252 \\
\hline
\end{tabular}

Panel D: Market Response to EOG around Three Event Dates

\begin{tabular}{lcccccc}
\hline Event & Pred. sign & $\begin{array}{c}\mathrm{N} \\
\text { Industry }\end{array}$ & $\begin{array}{c}\text { CAR } \\
\text { Industry } \\
\text { Mean } \\
\text { (Std. Dev) }\end{array}$ & $\begin{array}{c}\text { CAR } \\
\text { EOG } \\
\text { Mean } \\
\text { (Std. Dev) }\end{array}$ & Diff & P-value \\
\hline $\begin{array}{l}\text { Acknowledgement } \\
\text { of issues }\end{array}$ & - & 138 & 0.0518 & $\begin{array}{c}0.1232 \\
(\mathrm{n} / \mathrm{a})\end{array}$ & 0.0714 & 0.4816 \\
Restatement & - & 137 & $\begin{array}{c}(0.1008) \\
-0.1043\end{array}$ & $\begin{array}{c}-0.1114 \\
(\mathrm{n} / \mathrm{a})\end{array}$ & -0.0071 & 0.9465 \\
Bankruptcy & - & 136 & $\begin{array}{c}0.1059) \\
(0.1036)\end{array}$ & $\begin{array}{c}0.1095 \\
(\mathrm{n} / \mathrm{a})\end{array}$ & 0.1095 & 0.3151 \\
\hline
\end{tabular}




\section{TABLE 5}

\section{NBP Market Return and Accounting Performance over the 6 Months after the Enron Scandal}

This table presents the market return and accounting performance of Northern Border Partners (NBP), a subsidiary controlled by Enron, where Enron was responsible for performing the, over the periods after the Enron scandal. Panel A presents abnormal returns of NBP versus other firms in its industry over the 6 months following the end of the news related to the Enron scandal (3/1/2001 to 8/31/2002, based on the last scandal date from Chaney and Philipich 2002 February 3, 2002). Panel B presents the return on assets of NBP versus other firms in its industry at the quarter end of 2001, and Panel C presents the return on assets of NBP versus other firms in its industry over 2002. P values are two-tailed. ***, **, * indicate significant differences in means for each variable across subsamples at the one percent, five percent, or ten percent level, respectively.

Panel A: NBP Market Return over the 6 Months after the Enron Scandal

\begin{tabular}{|c|c|c|c|c|c|}
\hline & Pred. sign & $\begin{array}{l}\text { Abnormal } \\
\text { Return } \\
\text { Industry } \\
\text { Mean } \\
\text { (Std. Dev) }\end{array}$ & $\begin{array}{c}\text { Abnormal } \\
\text { Return } \\
\text { NBP } \\
\text { Mean } \\
\text { (Std. Dev) }\end{array}$ & Diff & $\mathrm{P}$-value \\
\hline $\mathrm{N}:$ & & 36 & 1 & & \\
\hline $\begin{array}{l}\text { Subsequent } 6 \\
\text { months }\end{array}$ & - & $\begin{array}{l}-0.2774 \\
(0.3338)\end{array}$ & $\begin{array}{c}-0.1734 \\
(\mathrm{n} / \mathrm{a})\end{array}$ & 0.1040 & 0.7604 \\
\hline
\end{tabular}

Panel B: Accounting Performance of NBP at the End of Quarter in 2001

\begin{tabular}{|c|c|c|c|c|c|}
\hline & Pred. sign & $\begin{array}{c}\text { ROA } \\
\text { Industry } \\
\text { Mean } \\
\text { (Std. Dev) }\end{array}$ & $\begin{array}{c}\text { ROA } \\
\text { NBP } \\
\text { Mean } \\
\text { (Std. Dev) }\end{array}$ & Diff & P-value \\
\hline $\begin{array}{l}\mathrm{N}: \\
12 / 31 / 2001 \\
\text { quarter end }\end{array}$ & - & $\begin{array}{c}36 \\
0.0068 \\
(0.0331) \\
\end{array}$ & $\begin{array}{c}1 \\
0.0075 \\
(\mathrm{n} / \mathrm{a})\end{array}$ & 0.0007 & 0.9833 \\
\hline
\end{tabular}


TABLE 5 (Continued)

NBP Market Return and Accounting Performance over the 6 Months after the Enron Scandal

Panel C: Accounting Performance of NBP over 2002

\begin{tabular}{|c|c|c|c|c|c|}
\hline & Pred. sign & $\begin{array}{c}\text { ROA } \\
\text { Industry } \\
\text { Mean } \\
\text { (Std. Dev) }\end{array}$ & $\begin{array}{c}\text { ROA } \\
\text { NBP } \\
\text { Mean } \\
\text { (Std. Dev) }\end{array}$ & Diff & $\mathrm{P}$-value \\
\hline $\mathrm{N}:$ & & 35 & 1 & & \\
\hline 2002 full year & - & $\begin{array}{c}0.0449 \\
(0.0481)\end{array}$ & $\begin{array}{c}0.0420 \\
(\mathrm{n} / \mathrm{a})\end{array}$ & -0.0029 & 0.9532 \\
\hline
\end{tabular}




\section{TABLE 6 \\ EOTT Market Return and Accounting Performance over the 6 Months after the Enron Scandal}

This table presents the market return and accounting performance of EOTT Energy (EOTT), a subsidiary not only controlled by Enron but also having close economic ties with Enron where Enron also controlled the accounting, over the periods after the Enron scandal. Panel A presents abnormal returns of EOTT versus other firms in its industry over the 6 months following the end of the news related to the Enron scandal (3/1/2001 to 8/31/2002, based on the last scandal date from Chaney and Philipich 2002 - February 3, 2002). We note that EOTT's negative return exceeds $100 \%$ - this is attributable to the fact that we use abnormal rather than raw returns. Panel $\mathrm{B}$ presents the return on assets of EOTT versus other firms in its industry at the quarter end of 2001. Because EOTT went bankrupt, there is no data for the full year 2002. P values are twotailed. $* * *, * *, *$ indicate significant differences in means for each variable across subsamples at the one percent, five percent, or ten percent level, respectively.

Panel A: EOTT Market Return over the 6 Months after the Enron Scandal

\begin{tabular}{|c|c|c|c|c|c|}
\hline & Pred. sign & $\begin{array}{l}\text { Abnormal } \\
\text { Return } \\
\text { Industry } \\
\text { Mean } \\
\text { (Std. Dev) }\end{array}$ & $\begin{array}{c}\text { Abnormal } \\
\text { Return } \\
\text { EOTT } \\
\text { Mean } \\
\text { (Std. Dev) }\end{array}$ & Diff & P-value \\
\hline $\mathrm{N}:$ & & 36 & 1 & & \\
\hline $\begin{array}{l}\text { Subsequent } 6 \\
\text { months }\end{array}$ & - & $\begin{array}{l}-0.2774 \\
(0.3338)\end{array}$ & $\begin{array}{c}-1.1142 \\
(\mathrm{n} / \mathrm{a})\end{array}$ & $-0.8402 * *$ & 0.0184 \\
\hline
\end{tabular}

Panel B: Accounting Performance of EOTT at the End of Quarter in 2001

\begin{tabular}{|c|c|c|c|c|c|}
\hline & Pred. sign & $\begin{array}{c}\text { Industry } \\
\text { ROA } \\
\text { Mean } \\
\text { (Std. Dev) }\end{array}$ & $\begin{array}{c}\text { EOTT } \\
\text { Mean } \\
\text { (Std. Dev) }\end{array}$ & Diff & P-value \\
\hline $\begin{array}{l}\text { N: } \\
12 / 31 / 2001 \\
\text { quarter end }\end{array}$ & - & $\begin{array}{c}36 \\
0.0068 \\
(0.0331) \\
\end{array}$ & $\begin{array}{c}1 \\
-0.0279 \\
(\mathrm{n} / \mathrm{a})\end{array}$ & -0.0347 & 0.3075 \\
\hline
\end{tabular}




\section{TABLE 7 \\ Future Accounting Performance of Subsidiaries}

This table examines the accounting performance of Enron's subsidiaries over a long horizon. Panel A presents the return on assets of KMP and NBP versus other firms in its industry at the five-quarters ending after Enron's announcement of bankruptcy (12/02/2019) and over the year 2001 and 2002, respectively. Panel B presents the return on assets of EOTT versus other firms in its industry. $\mathrm{P}$ values are two-tailed. $* * *, * *, *$ indicate significant differences in means for each variable across subsamples at the one percent, five percent, or ten percent level, respectively.

Panel A: Future Accounting Performance of KMP and NBP Relative to Their Peers

\begin{tabular}{|c|c|c|c|c|c|}
\hline & Pred. sign & $\begin{array}{c}\text { ROA (Industry) } \\
\text { Mean } \\
\text { (Std. Dev) } \\
\end{array}$ & $\begin{array}{c}\text { ROA (KMP \& NBP) } \\
\text { Mean } \\
\text { (Std. Dev) }\end{array}$ & Diff & P-value \\
\hline $\begin{array}{l}\mathrm{N}: \\
12 / 31 / 2001 \\
\text { quarter end }\end{array}$ & $+/-$ & $\begin{array}{c}36 \\
0.0068 \\
(0.0331)\end{array}$ & $\begin{array}{c}2 \\
0.0128 \\
(0.0074)\end{array}$ & 0.0060 & 0.8028 \\
\hline $\begin{array}{l}\mathrm{N}: \\
03 / 31 / 2002 \\
\text { quarter end }\end{array}$ & $+/-$ & $\begin{array}{c}32 \\
0.0109 \\
(0.0238)\end{array}$ & $\begin{array}{c}2 \\
0.015 \\
(0.0068)\end{array}$ & 0.0042 & 0.8092 \\
\hline $\begin{array}{l}\mathrm{N}: \\
06 / 30 / 2002 \\
\text { quarter end }\end{array}$ & $+/-$ & $\begin{array}{c}35 \\
0.0115 \\
(0.0123)\end{array}$ & $\begin{array}{c}2 \\
0.0150 \\
(0.0054)\end{array}$ & 0.0034 & 0.7002 \\
\hline $\begin{array}{l}\mathrm{N}: \\
09 / 30 / 2002 \\
\text { quarter end }\end{array}$ & $+/-$ & $\begin{array}{c}34 \\
0.0078 \\
(0.0135)\end{array}$ & $\begin{array}{c}2 \\
0.0156 \\
(0.0059)\end{array}$ & 0.0078 & 0.4271 \\
\hline $\begin{array}{l}\mathrm{N}: \\
12 / 31 / 2002 \\
\text { quarter end }\end{array}$ & $+/-$ & $\begin{array}{c}36 \\
0.0105 \\
(0.0149)\end{array}$ & $\begin{array}{c}2 \\
0.0144 \\
(0.0079)\end{array}$ & 0.0039 & 0.7200 \\
\hline $\begin{array}{l}\mathrm{N}: \\
2001 \text { full- } \\
\text { year }\end{array}$ & $+/-$ & $\begin{array}{c}36 \\
0.0487 \\
(0.0470)\end{array}$ & $\begin{array}{c}2 \\
0.0576 \\
(0.0287)\end{array}$ & 0.0089 & 0.7933 \\
\hline $\begin{array}{l}\mathrm{N}: \\
2002 \text { full- } \\
\text { year }\end{array}$ & $+/-$ & $\begin{array}{c}35 \\
0.0449 \\
(0.0481)\end{array}$ & $\begin{array}{c}2 \\
0.0613 \\
(0.0273)\end{array}$ & 0.0164 & 0.6376 \\
\hline
\end{tabular}


TABLE 7 (Continued)

Future Accounting Performance of Subsidiaries

Panel B: Future Accounting Performance of EOG Relative to Its Peers

\begin{tabular}{|c|c|c|c|c|c|}
\hline & Pred. sign & $\begin{array}{c}\text { ROA (Industry) } \\
\text { Mean } \\
\text { (Std. Dev) }\end{array}$ & $\begin{array}{c}\text { ROA (EOG) } \\
\text { Mean } \\
\text { (Std. Dev) }\end{array}$ & Diff & P-value \\
\hline $\begin{array}{l}\mathrm{N}: \\
12 / 31 / 2001 \\
\text { quarter end }\end{array}$ & $+/-$ & $\begin{array}{c}137 \\
-0.0276 \\
(0.0888)\end{array}$ & $\begin{array}{c}1 \\
-0.0073 \\
(\mathrm{n} / \mathrm{a})\end{array}$ & 0.0203 & 0.8198 \\
\hline $\begin{array}{l}\mathrm{N}: \\
03 / 31 / 2002 \\
\text { quarter end }\end{array}$ & $+/-$ & $\begin{array}{c}128 \\
0.0009 \\
(0.0293)\end{array}$ & $\begin{array}{c}1 \\
-0.0070 \\
(\mathrm{n} / \mathrm{a})\end{array}$ & -0.0079 & 0.7890 \\
\hline $\begin{array}{l}\mathrm{N}: \\
06 / 30 / 2002 \\
\text { quarter end }\end{array}$ & $+/-$ & $\begin{array}{c}134 \\
-0.0008 \\
(0.0938)\end{array}$ & $\begin{array}{c}1 \\
0.0108 \\
(\mathrm{n} / \mathrm{a})\end{array}$ & 0.0116 & 0.9023 \\
\hline $\begin{array}{l}\mathrm{N}: \\
09 / 30 / 2002 \\
\text { quarter end }\end{array}$ & $+/-$ & $\begin{array}{c}134 \\
0.0051 \\
(0.0291)\end{array}$ & $\begin{array}{c}1 \\
0.0079 \\
(\mathrm{n} / \mathrm{a})\end{array}$ & 0.0028 & 0.9241 \\
\hline $\begin{array}{l}\mathrm{N}: \\
12 / 31 / 2002 \\
\text { quarter end }\end{array}$ & $+/-$ & $\begin{array}{c}135 \\
-0.0045 \\
(0.0911)\end{array}$ & $\begin{array}{c}1 \\
0.0118 \\
(\mathrm{n} / \mathrm{a})\end{array}$ & 0.0163 & 0.8586 \\
\hline $\begin{array}{l}\text { N: } \\
2001 \text { full- } \\
\text { year }\end{array}$ & $+/-$ & $\begin{array}{c}154 \\
0.0141 \\
(0.2210)\end{array}$ & $\begin{array}{c}1 \\
0.1243 \\
(\mathrm{n} / \mathrm{a})\end{array}$ & 0.1102 & 0.6198 \\
\hline $\begin{array}{l}\mathrm{N}: \\
2002 \text { full- } \\
\text { year }\end{array}$ & $+/-$ & $\begin{array}{c}162 \\
0.0083 \\
(0.1093)\end{array}$ & $\begin{array}{c}1 \\
0.0241 \\
(\mathrm{n} / \mathrm{a})\end{array}$ & 0.0158 & 0.8857 \\
\hline
\end{tabular}




\section{TABLE 8}

\section{Market Reactions to Enron Events - Split by Institutional Ownership}

This table examines the market reaction to Enron's subsidiaries relative to their control group (high/low institutional ownership group). If the institutional ownership of a firm is higher than the median of the industry, we consider that a firm has high institutional ownership; if not, we consider it has low institutional ownership. Among the four subsidiaries, EOG belongs to the high institutional ownership group and the other three subsidiaries belong to the low institutional ownership group. This table does not include firms in EOG's industry. Panel A presents the cumulative abnormal return of the firms in the high institutional ownership group around the three major Enron's event. Panel B presents the cumulative abnormal return of the three subsidiaries (KMP, NBP, and EOTT) versus other firms in the low institutional ownership group around the three major Enron's event. Panel C presents the cumulative abnormal return of the firms in high versus low institutional ownership group around the three major events related to Enron. P values are two-tailed. ***, **,* indicate significant differences in means for each variable across subsamples at the one percent, five percent, or ten percent level, respectively.

Panel A: High Institutional Ownership Group

\begin{tabular}{lccc}
\hline Event & Pred. sign & $\begin{array}{c}\text { Industry } \\
\text { Return } \\
\text { Mean } \\
\text { (Std. Dev) }\end{array}$ & P-value \\
\hline $\mathrm{N}:$ & 16 & \\
Acknowledgement & - & -0.0165 & \\
of issues & & $(0.0780)$ & 0.4104 \\
Restatement & - & $-0.0573^{* *}$ & \\
& & $(0.0922)$ & 0.0252 \\
Bankruptcy & - & -0.0249 & 0.2653 \\
\hline
\end{tabular}

Panel B: Low Institutional Ownership Group

\begin{tabular}{lccccc}
\hline Event & Pred. sign & $\begin{array}{c}\text { Industry Return } \\
\text { Mean } \\
\text { (Std. Dev) }\end{array}$ & $\begin{array}{c}\text { Subsidiaries } \\
\text { Mean } \\
\text { (Std. Dev) }\end{array}$ & Diff & P-value \\
\hline N: & & 18 & 3 & & \\
Acknowledgement & $+/-$ & -0.0105 & -0.0237 & -0.0133 & 0.7385 \\
of issues & $(0.0648)$ & $(0.0420)$ & & \\
Restatement & $+/-$ & 0.0047 & -0.0646 & -0.0694 & 0.2963 \\
Bankruptcy & & $(0.1075)$ & $(0.0603)$ & & 0.5001 \\
\hline
\end{tabular}


TABLE 8 (Continued)

Market Reactions to Enron Events - Split by Institutional Ownership

Panel C: Control Group

\begin{tabular}{|c|c|c|c|c|c|}
\hline Event & Pred. sign & $\begin{array}{c}\text { High } \\
\text { Institutional } \\
\text { Ownership } \\
\text { Mean Ret } \\
\text { (Std. Dev) } \\
\end{array}$ & $\begin{array}{c}\text { Low } \\
\text { Institutional } \\
\text { Ownership } \\
\text { Mean Ret } \\
\text { (Std. Dev) } \\
\end{array}$ & Diff & P-value \\
\hline $\mathrm{N}$ : & & 16 & 18 & & \\
\hline $\begin{array}{l}\text { Acknowledgement } \\
\text { of issues }\end{array}$ & $+/-$ & $\begin{array}{l}-0.0165 \\
(0.0780)\end{array}$ & $\begin{array}{l}-0.0105 \\
(0.0648)\end{array}$ & 0.0061 & 0.8064 \\
\hline Restatement & $+/-$ & $\begin{array}{c}-0.0573 * * \\
(0.0922)\end{array}$ & $\begin{array}{c}0.0047 \\
(0.1075)\end{array}$ & $0.0620 *$ & 0.0824 \\
\hline Bankruptcy & $+/-$ & $\begin{array}{l}-0.0249 \\
(0.0886)\end{array}$ & $\begin{array}{l}-0.0449 \\
(0.0908)\end{array}$ & -0.0199 & 0.5175 \\
\hline
\end{tabular}


TABLE 9

\section{Market Reactions to Enron Events - Split by Analyst Coverage}

This table examines the market reaction to Enron's subsidiaries relative to their control group (high/low analyst coverage group). If the number of analysts following a firm is higher than the median of the industry, we consider that a firm has high analyst coverage; if not, we consider it has low analyst coverage. All of the four subsidiaries belong to high analyst coverage. This table does not include firms in EOG's industry. Panel A presents the cumulative abnormal return of the three subsidiaries (KMP, NBP, and EOTT) versus other firms in the high analyst coverage group around the three major Enron events. Panel B presents the cumulative abnormal return of the firms in low analyst coverage group around the three major Enron events. Panel C presents the cumulative abnormal return of the firms in high versus low analyst coverage group around the three major Enron events. $\mathrm{P}$ values are two-tailed. $* * *, * *, *$ indicate significant differences in means for each variable across subsamples at the one percent, five percent, or ten percent level, respectively.

Panel A: High Analyst Coverage Group

\begin{tabular}{|c|c|c|c|c|c|}
\hline Event & Pred. sign & $\begin{array}{l}\text { Industry } \\
\text { Return } \\
\text { Mean } \\
\text { (Std. Dev) }\end{array}$ & $\begin{array}{c}\text { Subsidiaries } \\
\text { Mean } \\
\text { (Std. Dev) } \\
\end{array}$ & Diff & P-value \\
\hline $\mathrm{N}:$ & & 18 & 3 & & \\
\hline $\begin{array}{l}\text { Acknowledgement } \\
\text { of issues }\end{array}$ & - & $\begin{array}{l}-0.0262 \\
(0.0523)\end{array}$ & $\begin{array}{l}-0.0237 \\
(0.0420)\end{array}$ & 0.0025 & 0.9397 \\
\hline Restatement & - & $\begin{array}{c}-0.0262 \\
(0.0804)\end{array}$ & $\begin{array}{c}-0.0646 \\
(0.0603)\end{array}$ & -0.0385 & 0.4436 \\
\hline Bankruptcy & - & $\begin{array}{c}-0.0292 \\
(0.0703)\end{array}$ & $\begin{array}{c}-0.0080 \\
(0.0172)\end{array}$ & 0.0213 & 0.6151 \\
\hline
\end{tabular}

Panel B: Low Analyst Coverage Group

\begin{tabular}{|c|c|c|c|}
\hline Event & Pred. sign & $\begin{array}{c}\text { Industry } \\
\text { Return } \\
\text { Mean } \\
\text { (Std. Dev) }\end{array}$ & P-value \\
\hline
\end{tabular}

\begin{tabular}{lccc}
$\mathrm{N}:$ & & 16 & \\
Acknowledgement & & 0.0012 & 0.9568 \\
of issues & $+/-$ & $(0.0857)$ & \\
& & -0.0227 & 0.4674 \\
Restatement & $+/-$ & $(0.1258)$ & \\
& & -0.0425 & 0.1305 \\
Bankruptcy & $+/-$ & $(0.1062)$ & \\
\hline
\end{tabular}


TABLE 9 (Continued)

Market Reactions to Enron Events - Split by Analyst Coverage

Panel C: Control Group

\begin{tabular}{|c|c|c|c|c|c|}
\hline Event & Pred. sign & $\begin{array}{c}\text { High } \\
\text { Analyst } \\
\text { Coverage } \\
\text { Mean Ret } \\
\text { (Std. Dev) }\end{array}$ & $\begin{array}{l}\text { Low Analyst } \\
\text { Coverage } \\
\text { Mean Ret } \\
\text { (Std. Dev) }\end{array}$ & Diff & P-value \\
\hline $\mathrm{N}$ : & & 18 & 16 & & \\
\hline $\begin{array}{l}\text { Acknowledgement } \\
\text { of issues }\end{array}$ & $+/-$ & $\begin{array}{l}-0.0262 \\
(0.0523)\end{array}$ & $\begin{array}{c}0.0012 \\
(0.0857)\end{array}$ & 0.0274 & 0.2634 \\
\hline Restatement & $+/-$ & $\begin{array}{l}-0.0262 \\
(0.0804)\end{array}$ & $\begin{array}{c}-0.0227 \\
(0.1258)\end{array}$ & 0.0035 & 0.9241 \\
\hline Bankruptcy & $+/-$ & $\begin{array}{c}-0.0292 \\
(0.0703)\end{array}$ & $\begin{array}{l}-0.0425 \\
(0.1062)\end{array}$ & -0.0133 & 0.6675 \\
\hline
\end{tabular}




\section{TABLE 10}

\section{Analyst Forecasts}

This table examines the timeliness and the frequency of analyst forecasts for the subsidiaries. Panel A presents the descriptive statistics of days between the IBES summary date (10/15/2001) and the next analyst forecast for the four subsidiaries, respectively. Earliest forecast is the first 2001 forecast made by each analyst after the summary date. Panel B presents the descriptive statistics of analyst forecasts frequency in 2001 . We calculate analyst forecast frequency as the number of analyst forecasts made by each analyst for 2001.

Panel A: Earliest Analyst Forecast

\begin{tabular}{lccccc}
\hline Subsidiaries & $\mathrm{N}$ & Min & Median & Mean & Max \\
\hline & & & & & \\
KMP & 2 & 3 & 18 & 18 & 33 \\
NBP & 8 & 8 & 16.5 & 26.75 & 63 \\
EOTT & 4 & 30 & 33 & 49 & 100 \\
EOG & 29 & 1 & 10 & 18.48 & 94 \\
\hline
\end{tabular}

Panel B: Analyst Forecast Frequency in 2001

\begin{tabular}{lccccc}
\hline Subsidiaries & $\mathrm{N}$ & Min & Median & Mean & Max \\
\hline KMP & 2 & 1 & 1 & 1 & 1 \\
NBP & 8 & 1 & 2 & 1.75 & 2 \\
EOTT & 4 & 1 & 2.5 & 2.5 & 4 \\
EOG & 29 & 1 & 3 & 3.45 & 9 \\
\hline
\end{tabular}




\section{TABLE 11}

\section{Returns of Restating/Bankrupt Firms versus Subsidiaries around Enron Events}

This table examines the market reaction to Enron's subsidiaries relative to other firms who restated or went bankrupt one year after Enron's scandal. Panel A presents the cumulative abnormal return of all of the four subsidiaries versus restating/bankrupt firms around the three major Enron events. Since EOTT went bankrupt in 2002, we individually compare EOTT versus restating/bankrupt firms. Panel B presents the cumulative abnormal return of the three subsidiaries (KMP, NBP, and EOG) versus the restating/bankrupt firms around the three major Enron events. Panel C presents the cumulative abnormal return of EOTT versus the restating/bankrupt firms around the three major Enron events. P values are two-tailed. ***, **,* indicate significant differences in means for each variable across subsamples at the one percent, five percent, or ten percent level, respectively.

Panel A: Restating/Bankrupt Firms versus All Subsidiaries

\begin{tabular}{lccccc}
\hline Event & Pred. sign & $\begin{array}{c}\text { Restating/Bankrupt } \\
\text { Firms } \\
\text { Mean Ret. } \\
\text { (Std. Dev) }\end{array}$ & $\begin{array}{c}\text { Subsidiaries } \\
\text { Mean Ret. } \\
\text { (Std. Dev) }\end{array}$ & Diff & P-value \\
\hline $\mathrm{N}:$ & 9 & 4 & & \\
$\begin{array}{l}\text { Acknowledgement } \\
\text { of issues }\end{array}$ & $+/-$ & 0.0721 & 0.0130 & -0.0591 & 0.4682 \\
Restatement & $+/-$ & $-0.1453)$ & $(0.0811)$ & & \\
Bankruptcy & $+/-$ & $-0.1112)$ & $(0.0545)$ & 0.0995 & 0.1225 \\
& + & -0.0216 & 0.0214 & 0.0430 & 0.2830 \\
\hline
\end{tabular}

Panel B: Restating/Bankrupt Firms versus 3 subsidiaries (KMP, NBP, and EOG)

\begin{tabular}{|c|c|c|c|c|c|}
\hline Event & Pred. sign & $\begin{array}{c}\text { Restating/Bankrupt } \\
\text { Firms } \\
\text { Mean Ret. } \\
\text { (Std. Dev) }\end{array}$ & $\begin{array}{l}\text { Subsidiaries } \\
\text { Mean Ret. } \\
\text { (Std. Dev) }\end{array}$ & Diff & P-value \\
\hline $\mathrm{N}:$ & & 9 & 3 & & \\
\hline $\begin{array}{l}\text { Acknowledgement } \\
\text { of issues }\end{array}$ & $+/-$ & $\begin{array}{c}0.0721 \\
(0.1453)\end{array}$ & $\begin{array}{c}0.0409 \\
(0.0720)\end{array}$ & -0.0312 & 0.7336 \\
\hline Restatement & $+/-$ & $\begin{array}{l}-0.1759 \\
(0.1112)\end{array}$ & $\begin{array}{c}-0.0899 \\
(0.0579)\end{array}$ & 0.0860 & 0.2381 \\
\hline Bankruptcy & $+/-$ & $\begin{array}{l}-0.0216 \\
(0.0644)\end{array}$ & $\begin{array}{c}0.0337 \\
(0.0675)\end{array}$ & 0.0553 & 0.2310 \\
\hline
\end{tabular}


TABLE 11 (Continued)

Returns of Restating/Bankrupt Firms versus Subsidiaries around Enron Events

Panel C: Restating/Bankrupt Firms versus EOTT

\begin{tabular}{lccccc}
\hline Event & Pred. sign & $\begin{array}{c}\text { Restating/Bankrupt } \\
\text { Firms } \\
\text { Mean Ret. } \\
\text { (Std. Dev) }\end{array}$ & $\begin{array}{c}\text { EOTT } \\
\text { Mean Ret. } \\
\text { (Std. Dev) }\end{array}$ & Diff & P-value \\
\hline $\mathrm{N}:$ & 9 & 1 & & \\
$\begin{array}{l}\text { Acknowledgement } \\
\text { of issues }\end{array}$ & $+/-$ & 0.0721 & -0.0707 & -0.1428 & 0.3786 \\
Restatement & $+/-$ & $(0.1453)$ & $(\mathrm{n} / \mathrm{a})$ & & \\
Bankruptcy & -0.1759 & -0.0357 & 0.0860 & 0.2658 \\
(n/a) & $(0.1112)$ & -0.0156 & 0.0060 & 0.9322 \\
\hline
\end{tabular}

